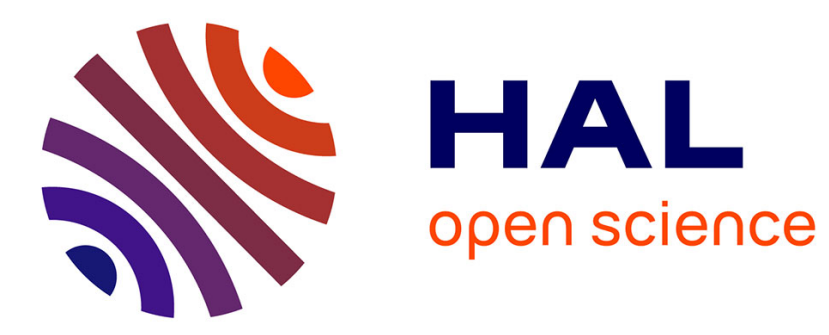

\title{
Milk proteins as encapsulation devices and delivery vehicles: Applications and trends
}

Guilherme Miranda-Tavares, Thomas Croguennec, Antonio F. Carvalho, Said Bouhallab

\section{- To cite this version:}

Guilherme Miranda-Tavares, Thomas Croguennec, Antonio F. Carvalho, Said Bouhallab. Milk proteins as encapsulation devices and delivery vehicles: Applications and trends. Trends in Food Science and Technology, 2014, 37, pp.5-20. 10.1016/j.tifs.2014.02.008 . hal-01209620

\section{HAL Id: hal-01209620 \\ https://hal.science/hal-01209620}

Submitted on 28 May 2020

HAL is a multi-disciplinary open access archive for the deposit and dissemination of scientific research documents, whether they are published or not. The documents may come from teaching and research institutions in France or abroad, or from public or private research centers.
L'archive ouverte pluridisciplinaire HAL, est destinée au dépôt et à la diffusion de documents scientifiques de niveau recherche, publiés ou non, émanant des établissements d'enseignement et de recherche français ou étrangers, des laboratoires publics ou privés. 


\section{Review}

Milk proteins as encapsulation devices and delivery vehicles: Applications
and trends

\author{
Guilherme M. Tavares ${ }^{\mathrm{a}, \mathrm{b}, \mathrm{c}}$, \\ Thomas Croguennec ${ }^{\mathrm{a}, \mathrm{b}}$, \\ Antonio F. Carvalho ${ }^{\mathrm{C}}$ and \\ Saïd Bouhallab ${ }^{\mathrm{a}, \mathrm{b}, *}$
}

aINRA, UMR1253 Science et Technologie du Lait et de I'Euf, F-35042 Rennes, France

${ }^{b}$ AGROCAMPUS OUEST,

UMR1253 Science et Technologie du Lait et de I'Euf, F-35042 Rennes, France (Tel.: + 33 223485742; e-mail: said.bouhallab@rennes.inra.fr)

${ }^{\mathrm{C}}$ Laboratory of Research in Milk Products, Universidade Federal de Viçosa, BR-36570 Viçosa, Brazil

Increasing the shelf-life of sensitive substances and targeting the release of nutritional/bioactive molecules are among the great challenges for the food industry. The development of food products with embedded encapsulation devices used to reach these objectives, constitutes a growing market. Milk proteins are biopolymers that are chemically and structurally versatile and are well adapted to several encapsulation purposes. Therefore, in this paper, the strategies, techniques, advantages and trends associated with the use of milk proteins as encapsulating device are reviewed. Special attention is given to the novel potential of reversibly co-assembled protein structures as encapsulating devices.

\section{* Corresponding author.}

0924-2244/\$ - see front matter $\odot 2014$ Elsevier Ltd. All rights reserved. http://dx.doi.org/10.1016/j.tifs.2014.02.008

\section{Introduction}

Encapsulation represents great potential regarding the development of innovative and functional products in the food industry (Sekhon, 2010). One of the initial objectives of encapsulation is to protect bioactive functional ingredients, microorganisms, etc. from adverse conditions (i.e., light, temperature, moisture or oxygen) through their incorporation within the core of an encapsulation device. Hence, the encapsulated material is preserved and the functionality and the shelf-life of the product are increased (Shahidi \& Han, 1993). More recently, the concept of encapsulation for the targeted and controlled release of encapsulated material has gained increasing interest because it allows the optimization of the concentration of the encapsulated material in the designed new products (Gouin, 2004).

Adding bioactives to food systems represents a simple way to develop functional foods that might provide physiological benefits or reduce the risk of diseases (Chen, Remondetto, \& Subirade, 2006). Combining these trends with the progress made in encapsulation techniques can increase the efficiency of the bioactives by increasing their solubility, bioavailability, stability or by controlling their release (Chen, Weiss, \& Shahidi, 2006). Moreover, the addition of bioactives might sometimes lead to an undesirable taste and odor in food, thus, encapsulation offers the possibility to develop products without flavor defects (Abd El-Salam \& El-Shibiny, 2012).

The controlled encapsulation efficiency and the release of encapsulated bioactives are directly connected to the technique and the conditions used for encapsulation. The release is accomplished by: (i) fracture of the shell structure, (ii) diffusion of the encapsulated molecule through the shell structure, (iii) dissolution or the melting of the shell structure, (iv) biodegradation of the shell structure, for example by enzymatic degradation (Shahidi \& Han, 1993). Thus, it is possible to select an encapsulation technique that offers the protection and/or controlled release of bioactives under specific physiological and technological conditions.

Encapsulation for the controlled release of bioactives has been largely studied and applied by pharmaceutical and cosmetic industries that have a larger investment capability than the food industry. For comparison and according to European commission, the ratio of $R \& D$ investment to net sales of the pharmaceutical industry in 2013 was $14.4 \%$ against $1.3 \%$ for food sector (Hernández et al., 
2013). One of the constraints of the food industry is that food products have to be designed for daily consumption, which raises the question of the safety and putative undesirable secondary effects of the encapsulation device. Nevertheless, the market for nanotechnology applied to food is growing rapidly. The growth of this market is attributed in part to the use of food proteins for the encapsulation, protection and transport of bioactives (Bovetto, Schmitt, Beaulieu, Carlier, \& Unterhaslberger, 2007; Danino, Livney, Ramon, Portnoy, \& Cogan, 2011; Livney \& Dalgleish, 2009; Schmitt \& Bovetto, 2007). The food proteins are structurally and chemically versatile biopolymers, with a high nutritional value and are Generally Recognized as Safe (GRAS) (Abd El-Salam \& El-Shibiny, 2012; Benshitrit, Levi, Tal, Shimoni, \& Lesmes, 2012). This is also true for milk proteins, which are the focus of this review.

Milk proteins are divided into two main groups: the caseins and the whey proteins (Table 1). Caseins are the fraction of proteins that precipitate at $\mathrm{pH} 4.6$ and are often considered intrinsically unstructured proteins (Farrell, Malin, Brown, \& Qi, 2006). In milk, caseins form highly hydrated colloidal particles called casein micelles (Walstra, Wouters, \& Geurts, 2006, Chap. 2 \& 3); on a dry-weight basis, casein micelles contain about $94 \%$ caseins and $6 \%$ minerals, mainly calcium phosphate. The caseins are synthesized exclusively in the mammary glands, suggesting that one of their functions is to provide amino acids required for the development of the neonate (Thompson, Boland, \& Singh, 2009, Chap. 3, 5 \& 6). Besides this function, caseins allow milk to be supersaturated in calcium phosphate, due to their capacity to bind divalent and multivalent ions. Due to this property, casein micelles are natural vehicles for calcium and phosphate delivery to neonates (Livney, 2010; Thompson et al., 2009).

In contrast, whey proteins are typically globular proteins and exhibit various biological functions. The major whey proteins in bovine milk, $\beta$-lactoglobulin and $\alpha$-lactalbumin, are exclusively synthesized in the mammary gland. It is assumed that these proteins are also responsible for providing amino acids to neonates. In addition, $\alpha$-lactalbumin acts as a coenzyme during milk synthesis and modulates the synthesis of lactose (Walstra et al., 2006). The structure of $\beta$-lactoglobulin is similar to that of retinolbinding proteins, even though little endogenous retinol is linked to $\beta$-lactoglobulin. Although $\beta$-lactoglobulin has several binding sites for hydrophobic ligands such as fatty acids and vitamins, the biological function of this protein is still not well defined (Thompson et al., 2009). In contrast, minor whey proteins e.g. blood serum albumin (BSA) and lactoferrin are transferred from blood plasma to milk through the lactating cell. The function of BSA is to transport minerals and hydrophobic molecules in blood plasma (Gelamo, Silva, Imasato, \& Tabak, 2002). Lactoferrin, a basic glycoprotein belonging to the family of iron-binding proteins, was reported to increase the bioavailability of iron and has bacteriostatic, antioxidant, anti-inflammatory and immunomodulatory properties (Thompson et al., 2009).

Due to the structural and functional diversity of milk proteins, several strategies have been described for their utilization as agents of encapsulation and for the transport of bioactives. Milk proteins can be used as carriers of hydrophobic molecules or ions and they are excellent interfacial agents used in the formation and stabilization of emulsions containing hydrophobic bioactives. They are also able to form covalent or electrostatic complexes with molecules of interest and to entrap bioactives through the formation of gels. Finally they are able to self-assemble or co-assemble to form supra-structures that allow the encapsulation and the transport of a diversity of small molecules (Livney, 2010). Although several comprehensive reviews on the encapsulation of various substances using food proteins alone or mixed with other biopolymers exist, to our knowledge, there are few papers that address the efficiency of milk proteins, which are the predominantly used food proteins. Hence, this review focuses on the use of milk proteins as agents of encapsulation and for the transport of bioactives, highlighting the strategies that have been developed to better explore the potential of these proteins. This review aims to illustrate that proteins occupy a specific niche among other biopolymers such as alginate, gum and kappa-carrageenan, which are frequently used as encapsulating devices. The review extends that by Chen, Remondetto, et al. (2006), which deals with food-grade protein materials for encapsulation. The final section

\begin{tabular}{|c|c|c|c|c|c|}
\hline \multirow{3}{*}{$\begin{array}{l}\text { Origin } \\
\begin{array}{l}\text { Synthesized in the } \\
\text { mammary gland }\end{array}\end{array}$} & \multicolumn{2}{|l|}{ Proteins } & \multirow{2}{*}{$\begin{array}{l}\text { Concentration in } \\
\text { milk }(\mathrm{g} / \mathrm{kg})\end{array}$} & \multirow{2}{*}{$\begin{array}{l}\text { Molecular weight }(\mathbf{k D a}) \\
\approx 10^{5}(100-500 \mathrm{~nm})\end{array}$} & \multirow{2}{*}{$\begin{array}{l}\text { Isoelectric point } \\
4.6\end{array}$} \\
\hline & \multicolumn{2}{|c|}{ Casein micelle } & & & \\
\hline & Caseins & $\alpha_{\mathrm{S} 1}$ & 10.7 & 23.6 & 4.9 \\
\hline & fractions & $\alpha_{\mathrm{S} 2}$ & 2.8 & 25.2 & 5.2 \\
\hline & & $\beta$ & 8.6 & 24 & 5.4 \\
\hline & & $\kappa$ & 3.1 & 19 & 5.6 \\
\hline & Whey & $\beta$-Lactoglobulin & 3.2 & 18.3 & 5.2 \\
\hline & proteins & $\alpha$-Lactalbumin & 1.2 & 14.2 & $4.3-4.7$ \\
\hline \multirow[t]{2}{*}{ From blood } & & BSA & 0.4 & 66.3 & 5.0 \\
\hline & & Lactoferrin & 0.1 & 83 & 8.5 \\
\hline
\end{tabular}


reports on the emerging potential of the spontaneous coassembly of milk proteins for encapsulation purposes.

\section{Techniques of encapsulation}

Many encapsulation techniques have been developed, but none is applicable to all bioactives (de Vos, Faas, Spasojevic, $\&$ Sikkema, 2010). The selection of a particular encapsulation technique depends on the nature of the bioactive and the coating material, as well as the properties of the particle to be designed, such as its size and morphology. In addition, inherent aspects relating to the encapsulation technique must be considered, such as the cost and encapsulation efficiency (Augustin \& Sanguansri, 2008). Several food components can interfere with the properties of bioactives at different stages of the product life cycle, therefore, it is essential that the selected encapsulation technique preserves the bioactives throughout the whole processing chain including engineering, formulation and storage of the products (Gibbs, Kermasha, Alli, \& Mulligan, 1999). In addition, it is also important to ensure the production of encapsulation devices that can be easily incorporated into food products without altering texture and flavor (de Vos et al., 2010).

The most widely used encapsulation techniques and some related applications are summarized in Table 2. Furthermore, some procedures have been specifically developed to optimize the potential of biopolymers such as milk proteins as encapsulating agents. Several articles have summarized the potential of milk proteins to transport and protect bioactives such as ions, fatty acids and vitamins (Chen, Remondetto, et al., 2006; Elzoghby, El-Fotoh, \& Elgindy, 2011; Livney, 2010; Velikov \& Pelan, 2008). Additionally, two distinct and complementary approaches i.e., "top-down" and "bottom-up", have been explored to widen the use of milk proteins as encapsulating biomaterials.

The "top-down" approach consists of the fragmentation of a large structure into smaller particles through external energy input, especially mechanical energy (Chen, Remondetto, et al., 2006; Velikov \& Pelan, 2008). The

Table 2. Main conventional techniques used for the encapsulation of bioactives and food ingredients. Please refer to the following papers for more details: Augustin \& Sanguansri, 2008; Gouin, 2004; Shahidi \& Han, 1993; de Vos et al., 2010.

\begin{tabular}{|c|c|c|}
\hline Technique & Concept & Examples of applications \\
\hline Spray drying & $\begin{array}{l}\text { Drying of the encapsulated material dispersed in the shell material. } \\
\text { Encapsulation by starch, polysaccharides, maltodextrins and/or proteins. } \\
\text { This technique produces particles between } 10 \text { and } 100 \mu \mathrm{m}\end{array}$ & $\begin{array}{l}\text { Encapsulation of flavor } \\
\text { compounds, polyphenols } \\
\text { and vitamins }\end{array}$ \\
\hline $\begin{array}{l}\text { Spray cooling/ } \\
\text { chilling }\end{array}$ & $\begin{array}{l}\text { Incorporation of the core material in the warm and liquefied shell material } \\
\text { (often vegetable oils). Relatively low-cost encapsulation technique. Through } \\
\text { product atomization, and consequently cooling, micro-capsules are formed }\end{array}$ & $\begin{array}{l}\text { Encapsulation of flavor compounds, } \\
\text { minerals, vitamins and probiotics }\end{array}$ \\
\hline Freeze drying & $\begin{array}{l}\text { Co-lyophilization of the core and the shell materials after a homogenization } \\
\text { process. Normally this technique produces non-uniform particles }\end{array}$ & $\begin{array}{l}\text { Encapsulation of flavor compounds, } \\
\text { fatty acids and probiotics }\end{array}$ \\
\hline Extrusion & $\begin{array}{l}\text { Formation of core material droplets that became microparticles after } \\
\text { immersion in a hardening bath with the shell material. Normally the shell } \\
\text { material is a glassy carbohydrate matrix. The core material may be released } \\
\text { in a high temperature medium. The encapsulation efficiency is small, moreover } \\
\text { the produced particles show high stability and an extended shelf-life }\end{array}$ & $\begin{array}{l}\text { Encapsulation of flavor compounds, } \\
\text { vitamins and food ingredients } \\
\text { (lactic acid) }\end{array}$ \\
\hline Spinning disk & $\begin{array}{l}\text { Passage through a spinning disk of a suspension of the core } \\
\text { material in the shell material. During processing, the shell material } \\
\text { forms a thin film around the core material particles. Production of particles } \\
\text { from } 20 \mu \mathrm{m} \text { to few millimeters of diameter }\end{array}$ & Encapsulation of cells (yeast) \\
\hline $\begin{array}{l}\text { Supercritical fluid } \\
\text { extraction }\end{array}$ & $\begin{array}{l}\text { This technique is similar to spray drying, except that the shell material and the } \\
\text { core material are solubilized/dispersed in a supercritical fluid }\end{array}$ & $\begin{array}{l}\text { Encapsulation of heat-sensible cores } \\
\text { as vitamins and polyphenols }\end{array}$ \\
\hline Fluidized bed & $\begin{array}{l}\text { This technique is applied for solid particle encapsulation }(100 \mu \mathrm{m} \text { to few } \mathrm{mm}) \text {. } \\
\text { The shell material is atomized onto core material fluidized by an } \\
\text { upward stream of air }\end{array}$ & $\begin{array}{l}\text { Encapsulation of acidulates, } \\
\text { vitamins and cells }\end{array}$ \\
\hline Cocrystallization & $\begin{array}{l}\text { Spontaneous crystallization of a supersaturated solution of sucrose simultaneously } \\
\text { with the addition of the core material, forming a crystalline irregular network, } \\
\text { allowing the encapsulation into the pores of the network }\end{array}$ & $\begin{array}{l}\text { Encapsulation of acids, flavor } \\
\text { compounds, antioxidants } \\
\text { and minerals }\end{array}$ \\
\hline Coacervation & $\begin{array}{l}\text { Phase separation of one or many polyelectrolytes from a solution and deposition } \\
\text { of the colloidal particles around the active ingredient suspended or emulsified in } \\
\text { the same reaction media. When hydrocolloids are used, they can be cross-linked } \\
\text { using appropriate chemical or enzymatic agent }\end{array}$ & $\begin{array}{l}\text { Encapsulation of fatty } \\
\text { acids and flavonoids }\end{array}$ \\
\hline Liposomes & $\begin{array}{l}\text { Spherical particles consisting of a membranous system formed by one or more } \\
\text { concentric bi-layers of lipids (often phospholipids). They can be used in the } \\
\text { entrapment, delivery and released of water-soluble, lipid-soluble } \\
\text { and amphiphilic materials }\end{array}$ & $\begin{array}{l}\text { Encapsulation of vitamins, } \\
\text { enzymes and peptides }\end{array}$ \\
\hline Inclusion & $\begin{array}{l}\text { This technique refers to the supra-molecular association through } \\
\text { non-covalent interactions of a ligand ("encapsulated" compound) into a } \\
\text { cavity formed by a "shell" material (e.g., cyclodextrins) }\end{array}$ & $\begin{array}{l}\text { Encapsulation of vitamins, } \\
\text { flavor compounds and essential oils }\end{array}$ \\
\hline
\end{tabular}


formed particles have the same composition as the initial structure (Velikov \& Pelan, 2008). The initial structure can be a preformed protein hydrogel and particles of definite size are obtained using the "top-down" approach. The formed particles have the ability to entrap and transport micronutrients and bioactive compounds. Several gelling strategies are available for encapsulating the bioactives in the preformed protein hydrogel: enzymatic-induced gelation (Heidebach, Forst, \& Kulozik, 2009a, 2009b), heatinduced gelation (Betz \& Kulozik, 2011) and cold-set gelation (Martin \& de Jong, 2012a, 2012b). Protein cold-set gelation is particularly useful for encapsulating heatsensitive bioactives, including probiotics (Chen, Remondetto, et al., 2006) and occurs in two steps; the first step involves an unfolding of the globular proteins (by a thermal treatment), resulting in the exposure of some reactive groups. After cooling and the addition of the heatsensitive molecules of interest, the second step consists of a cold aggregation of the denatured proteins through a reduction in electrostatic repulsions, by decreasing $\mathrm{pH}$ or/ and adding salts (Alting, de Jongh, Visschers, \& Simons, 2002; Martin \& de Jong, 2012b). Another advantage of this method is that reactive groups exposed during the heat treatment of the proteins might establish interactions with the bioactives (Chen, Remondetto, et al., 2006).

In contrast, the "bottom-up" approach is based on the association of molecules or small particles into larger and more complex supra-structures (Chen, Remondetto, et al., 2006; Viney, 2004). This approach allows a better kinetic and thermodynamic control of the supra-structure formation, but it is often more complex to implement. In addition, the "bottom-up" approach usually requires less energy input than the "top-down" approach (Velikov \& Pelan, 2008). The assembly of proteins into supra-structures might be induced differently according to the applied chemical or physical treatments and energy input. Examples of structures generated either from caseins or whey proteins are illustrated in Fig. 1. For instance, different structures have been generated from whey proteins, depending on the intensity of the heat treatment applied (Bengoechea, Peinado, \& McClements, 2011), the combination of heat treatment and variations of ionic strength and/or $\mathrm{pH}$ conditions (Giroux, Houde, \& Britten, 2010). Another possibility consists of the spontaneous protein interactions that are driven and stabilized by weak reversible interactions, including electrostatic, hydrophobic and hydrogen interactions, or salt bridges (Desfougeres, Croguennec, Lechevalier, Bouhallab, \& Nau, 2010; Esmaili et al., 2011; Semo, Kesselman, Danino, \& Livney, 2007). A large variety of supra-structures can be obtained by changing the nature and concentration of the proteins, the concentration and type of salts, in the presence or absence of specific enzymes or by modulating the temperature. This variety of supra-structures represents a great potential regarding the encapsulation of bioactives. Protein assembly can also be triggered through protein desolvation in the presence of organic solvents (Gulseren, Fang, \& Corredig, 2012a, 2012b; Gunasekaran, Ko, \& Xiao, 2007; Ko \& Gunasekaran, 2006). Thus, heat-denatured proteins in aqueous solution form nanoparticles of about 100-200 $\mathrm{nm}$ subsequent to modification of the solvent properties following the addition of organic solvents such as acetone or ethanol. The change in solvent properties strengthens hydrogen bonds and reduces hydrophobic associations between heat-denatured proteins (Gulseren et al., 2012a; Ko \& Gunasekaran, 2006). These nanoparticles, which can be further stabilized using a cross-linking reagent, are suitable for the encapsulation and transport of micronutrients (Gulseren et al., 2012b) and bioactives (Gunasekaran et al., 2007). Recently, milk proteins have been used to form nano- and micro-capsules by electrospraying (López-Rubio \& Lagaron, 2012; López-Rubio, Sanchez, Wilkanowicz, Sanz, \& Lagaron, 2012). Electrospraying is a versatile and low-cost technique that is easy to implement and allows the production of capsules or fibers (in this case the technique is called electrospinning) from polymer solutions (Torres-Giner \& Lagaron, 2010). Charges are induced on the surface of the liquid jet or droplet through the application of an electric field, which generates a repulsive force opposite to that of surface tension; while the jet or the droplet is exposed to the electric field, the solvent evaporates, generating fibers or capsules (Doshi \& Reneker, 1995). Usually, organic solvents are used for the dissolution of the polymers (polyethylene glycol, polyvinylchloride, polystyrene). The advantage of using biopolymers such as proteins, is that the electrospraying technique can be applied in aqueous solution (López-Rubio \& Lagaron, 2012). This technique was used for the production of nano-, sub-micro- and microcapsules from solutions of whey protein concentrate (WPC) at different $\mathrm{pH}$ values, to encapsulate $\beta$-carotene in the presence of glycerol (López-Rubio \& Lagaron, 2012). The authors reported an encapsulation rate of about $90 \%$, with a good stability of $\beta$-carotene against photooxidation after resolubilization of the capsules and exposure of the solution to UV radiation for $50 \mathrm{~h}$.

\section{Milk proteins as encapsulating biomaterial of biomolecules and microorganisms}

Several recent reviews have dealt with the combination of milk proteins and polysaccharides for encapsulating various bioactives (Aberkane et al., 2012; Matalanis \& McClements, 2013; Serrano-Cruz, Villanueva-Carvajal, Rosales, Davila, \& Dominguez-Lopez, 2013; Zimet \& Livney, 2009). The present review focuses on the use of milk proteins as unique encapsulation agents. Milk proteins are interesting encapsulation agents because of their ability to bind different bioactives or to entrap them through the formation of supra-molecular structures, emulsions or hydrogels. The main strategies applied for encapsulation that involve milk proteins are summarized in Fig. 2. Although the same strategies apply for whey proteins and caseins, 


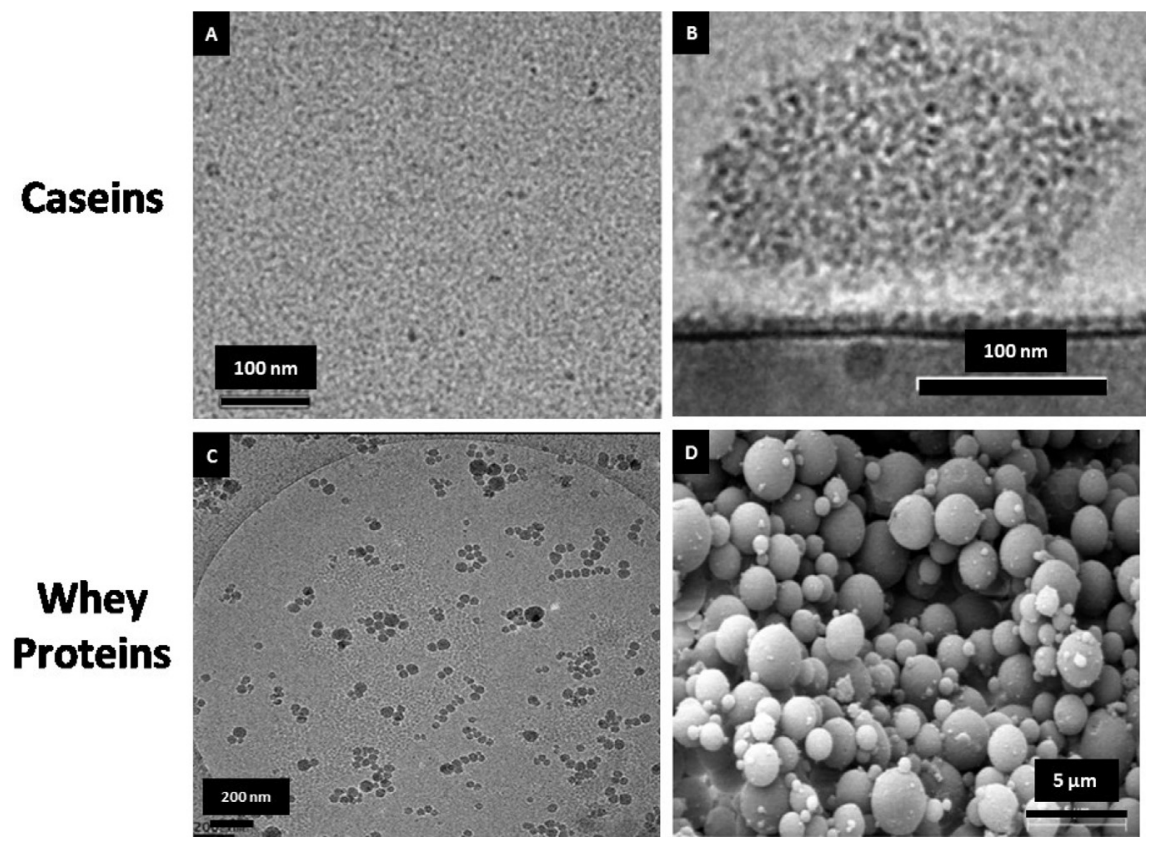

Fig. 1. Application of a "bottom-up approach" to generate supra-molecular structures from caseins or whey proteins. (A) Cryo-TEM image of micelles of about 15-20 nm created from $\beta$-casein (adapted from Shapira et al., 2012). (B) Cryo-TEM image of re-assembled casein micelles $\left(200-250 \mathrm{~nm}\right.$ ) with encapsulated vitamin $\mathrm{D}_{2}$ (adapted from Semo et al., 2007). (C) Cryo-TEM image of whey protein nanoparticles $(\approx 50 \mathrm{~nm})$ obtained through desolvation (adapted from Gulseren et al., 2012a). (D) SEM image of capsules ( $\approx 2 \mu \mathrm{m}$ ) of whey protein concentrate obtained through electrospraying (adapted from López-Rubio \& Lagaron, 2012).

different approaches based on protein specificities have been used to increase the encapsulation potential of each type of protein. Table 3 gives a non-exhaustive list of studies that have used milk proteins as encapsulation agents or delivery vehicles, as well as the corresponding encapsulated compounds. These studies are classified according to the applied encapsulation strategy.

\section{Caseins}

Binding properties of casein

Due to its sponge-like structure consisting of internal cavities connected to each other and to the porous surface by channels, casein micelles were presumed for a long time, to protect and transport molecules of interest. The ability of "native" casein micelles but also isolated casein

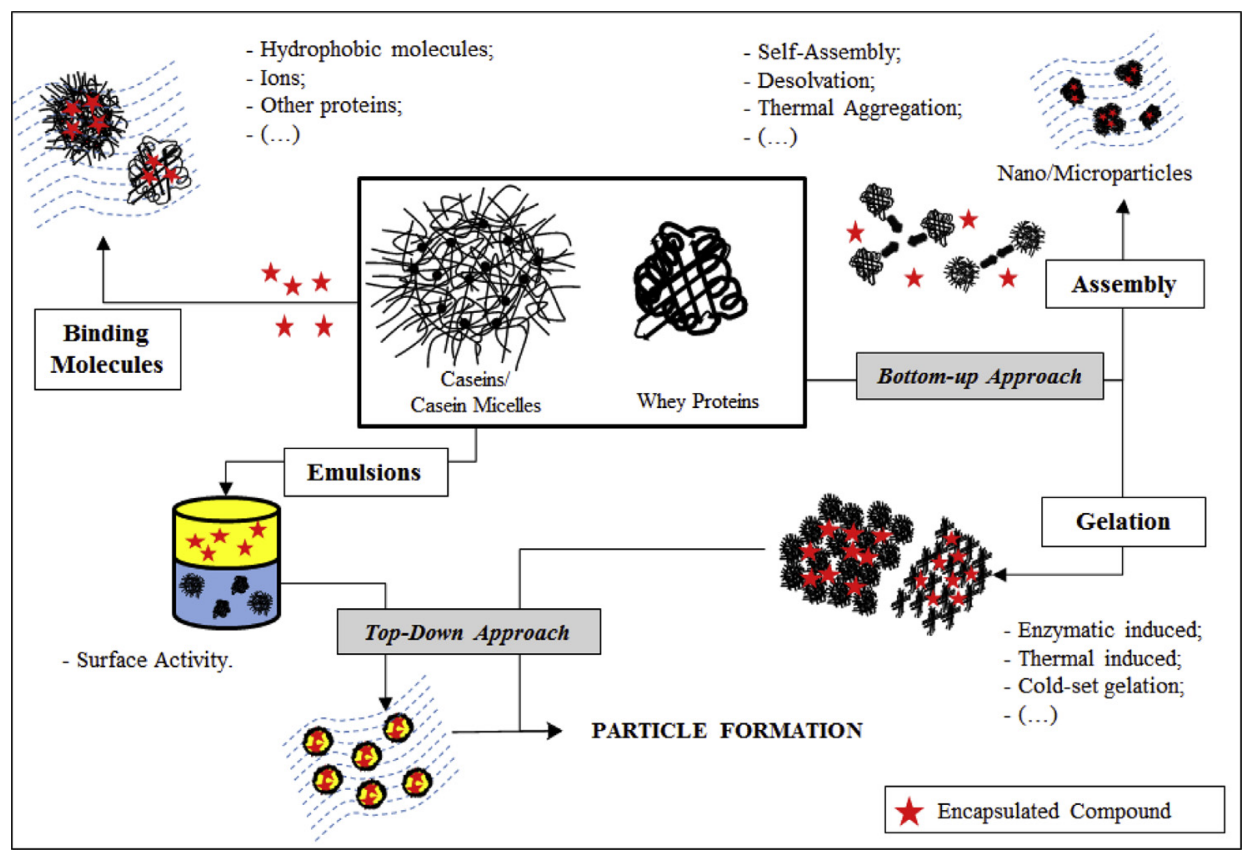

Fig. 2. Illustration of encapsulation strategies applied to milk proteins. 


\begin{tabular}{|c|c|c|c|c|}
\hline Proteins & \multicolumn{2}{|c|}{ Encapsulation strategy } & Encapsulated compounds & References \\
\hline \multirow[t]{3}{*}{$\begin{array}{l}\text { Whey } \\
\text { proteins }\end{array}$} & \multicolumn{2}{|l|}{ Binding } & $\begin{array}{l}\text { Flavor compounds, hydrophobic and } \\
\text { hydrophilic vitamins (vitamin } \mathrm{D}_{3,} \\
\text { vitamin } \mathrm{E} \text { and vitamin } \mathrm{B}_{9} \text { ), polyphenols } \\
\text { (resveratrol and curcumin, catechins), } \\
\text { fatty acids and minerals (iron) }\end{array}$ & $\begin{array}{l}\text { (Diarrassouba et al., 2013; Le Maux et al., 2012; } \\
\text { Liang et al., 2011; Zorilla et al., 2011) }\end{array}$ \\
\hline & \multicolumn{2}{|c|}{ Bottom-up approach } & $\begin{array}{l}\text { Flavor compounds, hydrophobic vitamins } \\
\text { (vitamin E), polyphenols (curcumin, } \\
\text { catechins, quercetin, kaempferol and rutin), } \\
\text { drugs and minerals (zinc) }\end{array}$ & $\begin{array}{l}\text { (Giroux \& Britten, 2011; Gong et al., 2009; } \\
\text { Gulseren et al., 2012a; Shpigelman et al., 2012) }\end{array}$ \\
\hline & $\begin{array}{l}\text { Top-down } \\
\text { approach }\end{array}$ & $\begin{array}{l}\text { Hydrogel/ } \\
\text { hydrogel } \\
\text { particles } \\
\text { Emulsion }\end{array}$ & $\begin{array}{l}\text { Hydrophobic vitamins (vitamin A, vitamin E), } \\
\text { flavonoids (anthocyanin), cells (probiotics, } \\
\text { yeasts) and minerals (iron) } \\
\text { Hydrophobic vitamins (vitamin A, vitamin } \\
D_{3} \text {, vitamin E), fish oil, essential oils and } \\
\text { polyphenols (resveratrol) }\end{array}$ & $\begin{array}{l}\text { (Betz \& Kulozik, 2011; Doherty et al., 2011; } \\
\text { Liang et al., 2010; Somchue, Sermsri, } \\
\text { Shiowatana, \& Siripinyanond, 2009) } \\
\text { (Hemar, Cheng, Oliver, Sanguansri, \& Augustin, } \\
\text { 2010; Hong, Surassmo, Chun, Min, \& Choi, 2012; } \\
\text { Liang et al., 2010; Tippetts et al., 2012) }\end{array}$ \\
\hline \multirow{4}{*}{$\begin{array}{l}\text { Casein } \\
\text { fractions } \\
\text { and casein } \\
\text { micelles }\end{array}$} & \multicolumn{2}{|l|}{ Binding } & $\begin{array}{l}\text { Flavor compounds, flavonoids, minerals } \\
\text { (iron) and other proteins }\end{array}$ & $\begin{array}{l}\text { (Anema \& de Kruif, 2012; Raouche, } \\
\text { Dobenesque, et al., 2009; Sahlan \& Pramadewi, } \\
\text { 2012; Sangeetha \& Philip, 2012) }\end{array}$ \\
\hline & \multicolumn{2}{|c|}{ Bottom-up approach } & $\begin{array}{l}\text { Polyphenols (curcumin, tannin), hydrophobic } \\
\text { vitamins (vitamin } A \text {, vitamin } D_{2} \text {, vitamin } D_{3} \text { ), } \\
\text { fatty acids and drugs }\end{array}$ & $\begin{array}{l}\text { (Ma et al., 2012; Saiz-Abajo et al., 2013; } \\
\text { Shapira et al., 2012; Zimet, Rosenberg, } \\
\text { \& Livney, 2011) }\end{array}$ \\
\hline & \multirow[t]{2}{*}{$\begin{array}{l}\text { Top-down } \\
\text { approach }\end{array}$} & $\begin{array}{l}\text { Hydrogel/ } \\
\text { hydrogel } \\
\text { particles }\end{array}$ & Probiotic cells & (Heidebach et al., 2009a, 2009b) \\
\hline & & Emulsion & $\begin{array}{l}\text { Hydrophobic vitamins (vitamin } \mathrm{A} \text {, vitamin } \mathrm{D}_{3} \text { ), } \\
\text { fish oil, essential oils and polyphenols } \\
\text { (resveratrol) }\end{array}$ & $\begin{array}{l}\text { (Cornacchia \& Roos, 2011; Hemar et al., } \\
\text { 2010; Matalanis et al., 2012; } \\
\text { Tippetts et al., 2012) }\end{array}$ \\
\hline
\end{tabular}

fractions and caseinates to interact with hydrophobic molecules and minerals has been the subject of extensive investigations.

Sahlan and Pramadewi (2012) tested the ability of caseins to encapsulate flavonoids, by isolating a casein fraction from cow milk by combining a slight reduction of $\mathrm{pH}$ and a rennet hydrolysis. Casein nanoparticles with a mean diameter of $109 \mathrm{~nm}$, close to the diameter of native casein micelles, were obtained (Table 1), which possessed an encapsulation efficiency of about $42 \%$, corresponding to an encapsulation of almost $1.0 \mathrm{mg}$ flavonoid per gram of casein (Sahlan \& Pramadewi, 2012). Casein micelles were also tested for their ability to stabilize minerals in supplemented foods. Raouche, Naille, et al. (2009) used a reversible acidification process by carbonation to enhance the iron content in the casein colloidal fraction of skimmed milk. For the tested concentrations $(2-20 \mu$ moles of iron per liter of milk), the proportion of iron recovered in the casein fraction reached about $95 \%$. This very high recovered proportion demonstrates the efficiency of the carbonation process to increase significantly the iron retention in casein micelles. The process of acidification by carbonation probably reduced competition between iron and calcium ions for casein phosphoseryl sites. The interaction between calcium and the casein phosphoserine residues is known to be affected by both $\mathrm{pH}$ and ionic strength: increasing ionic strength and decreasing $\mathrm{pH}$ reduce the affinity of casein for calcium. In contrast, the interaction between iron and the casein phosphoserine residues is less affected by $\mathrm{pH}-$ change because iron binding involves electrostatic interaction and coordination links. Consequently, calcium was partially removed from the casein micelles during carbonation, allowing its substitution by iron atoms (Raouche, Naille, et al., 2009). Supplementation with iron modified the properties of the casein micelles by decreasing the zeta potential, hydration and thermal stability of the casein micelles; in addition, it slowed down the enzymatic coagulation kinetic of casein micelles (Raouche, Dobenesque, Bot, Lagaude, \& Marchesseau, 2009). Compared to whey proteins, caseins exhibit a higher ability to stabilize iron (Sugiarto, Ye, \& Singh, 2009). The ability of casein micelles to encapsulate iron under magnetic field was reported by Sangeetha and Philip (2012). These authors produced stable iron oxide nanoparticle-casein nano-complexes that can reversibly self-assemble after application of an external magnetic field. In an initial step, iron oxide nanoparticles interact with the casein micelle surface. Due to their positive charges, the nanoparticles could bridge several casein micelles, leading to aggregates with a hydrodynamic size of about $615 \mathrm{~nm}$. In a second step, the application of ultrasound broke these bridges and facilitated the penetration of the nanoparticles into the hydrophobic core of the micelles, leading to iron oxide-casein micelle complexes with a hydrodynamic size of about140 nm (Sangeetha \& Philip, 2012). Apart from these studies, a significant reduction in casein solubility subsequent to their 
interaction with iron was generally observed, which consequently limited the use of casein for encapsulation and iron transport. In addition to the use of casein structure as a carrier for small molecules, the ability of casein to interact and encapsulate larger molecules such as globular proteins constitutes a recent research interest. Some studies are dedicated to the encapsulation of lactoferrin, given its high nutritional and biological value and have reported the interaction of casein micelles with lactoferrin. The addition of lactoferrin to skimmed milk resulted in the binding of lactoferrin to casein micelles (Anema \& de Kruif, 2011). Subsequent to the formation of complexes, a slow process of casein micelle disintegration was observed, which resulted in an increase in milk transparency, with a kinetic that was about 10-fold slower than the binding kinetic (Anema \& de Kruif, 2011). The observed disintegration appears to be complex and a specific phenomenon, as it was not induced by adding lysozyme, another basic protein. The disintegration of the casein micelle can be prevented by cross-linking the casein molecules using transglutaminase before adding lactoferrin to milk (Anema \& de Kruif, 2012). Hypothetically, the interaction between the casein micelles and lactoferrin is mainly directed by electrostatic bonds, but some binding sites are also hidden within the hydrophobic core of the casein micelles. The latter are more or less accessible, according to the physico-chemical conditions of the medium (Croguennec, Li, Phelebon, Garnier-Lambrouin, \& Gesan-Guiziou, 2012).

\section{Encapsulation devices obtained through the "bottom-up" approach}

The use of caseins for the encapsulation of bioactives via the bottom-up approach is illustrated by the re-assembly of caseinate particles $(30-50 \mathrm{~nm})$ or the self-assembly of $\beta$-casein into structures having a micelle-like appearance. $\beta$-Casein is selectively isolated from casein micelles and possesses self-assembly properties according to temperature and casein concentration conditions.

Semo et al. (2007) applied the re-assembly of caseinate to encapsulate vitamin $\mathrm{D}_{2}$. The re-assembly process was triggered by successive additions of a mixture of potassium hydrogen phosphate and calcium chloride, dropped into a solution of sodium caseinate and tri-potassium phosphate. The authors obtained casein micelle-like structures with a diameter of about $156 \mathrm{~nm}$, which allowed an efficient encapsulation of vitamin $\mathrm{D}_{2}$ of approximately $27 \%$. In this way, vitamin $D_{2}$ was efficiently protected against photochemical degradation. These casein supra-molecular structures were also effective in the protection of thermolabile $\beta$-carotene against thermal degradation during industrial processes such as pasteurization, sterilization and baking (Saiz-Abajo, Gonzalez-Ferrero, Moreno-Ruiz, Romo-Hualde, \& Gonzalez-Navarro, 2013). The studies dedicated to the nanoencapsulation of $\beta$-carotene using various encapsulation materials including caseins have been recently reviewed by Gutiérrez et al. (2013). A similar re-assembly process was used to form casein micelle-like structures from sodium caseinate to encapsulate vitamin $\mathrm{D}_{3}$ (Haham et al., 2012). The obtained supra-molecular structures were further homogenized at a pressure of $155 \mathrm{MPa}$ and the protective effect against thermal and oxidative degradation of the vitamin was analyzed. Prior to homogenization, the supra-molecular structures exhibited a bimodal size distribution, with a major population smaller than $100 \mathrm{~nm}$ in diameter and a sub-population between 200 and $400 \mathrm{~nm}$ in diameter. The homogenization step reduced the proportion of larger-size particles, although the mean diameter of the two populations was mainly unchanged. The homogenization step did not affect the thermal stability of vitamin $\mathrm{D}_{3}$ under the tested conditions $\left(80{ }^{\circ} \mathrm{C} / 1 \mathrm{~min}\right)$, but it reduced its degradation kinetic during cold storage for a period of 28 days. Improved stability was achieved, since vitamin that was encapsulated in casein micelle-like structures exhibited a degradation rate of $40 \%$ and $10 \%$ before and after homogenization respectively, whereas a major part $(>70 \%)$ of free nonencapsulated vitamin was degraded. The improved protection observed for the homogenized sample was attributed to a better distribution of the vitamin into the supra-molecular structures (Haham et al., 2012). According to a clinical trial conducted on 87 healthy volunteers, the bioavailability of the vitamin encapsulated in a casein matrix was at least as good as that found for more classical tween 80emulsified $\mathrm{VD}_{3}$ supplement. Nevertheless, the nanoencapsulation of vitamin $\mathrm{D}_{3}$ with caseins offers a protective advantage in enriched foods (Haham et al., 2012).

Esmaili et al. (2011) self-assembled $\beta$-casein with the aim to encapsulate curcumin. In the presence of $10 \mathrm{~g} \mathrm{~L}^{-1}$ $\beta$-casein above the protein critical micelle concentration, the solubility of curcumin was increased at least 2500 times. Simultaneously, the cytotoxicity of curcumin against human leukemia cells and its antioxidant activity slightly increased after encapsulation (Esmaili et al., 2011). The authors proposed to use $\beta$-casein as a nanovehicle for this hydrophobic component but do not comment further on the enhanced cell cytotoxicity. Bohin, Vincken, van der Hijden, and Gruppen (2012) worked with the micellization of bovine $\beta$-casein for the encapsulation of phenolic components such as epigallocatechin-3-gallate (EGCG) at $25{ }^{\circ} \mathrm{C}$ and $\mathrm{pH}$ 7.0. Under these conditions, $\beta$-casein micelles with a mean diameter of about $13 \mathrm{~nm}$ were formed. These allowed the encapsulation of about $38 \mathrm{~g}$ EGCG per $100 \mathrm{~g}$ of protein (Bohin et al., 2012). Ma, Baron, Guyot, Bouhallab, and Zanchi (2012) concluded that the kinetic of association of EGCG with $\beta$-casein micelles showed a very rapid first phase (in the order of $100 \mathrm{~ms}$ ), which corresponded to the uptake of tannins by $\beta$-casein micelles, followed by a slow second step relative to the reorganization of the system, based on the diffusion of tannins into $\beta$-casein, the micelle core. Similarly, $\beta$-casein micelles were used to encapsulate a hydrophobic drug used in the treatment of gastric cancer (Shapira, Assaraf, Epstein, \& 
Livney, 2010; Shapira, Davidson, Avni, Assaraf, \& Livney, 2012). Under the applied conditions, the micelles showed an encapsulation efficiency of almost $100 \%$. The encapsulation device was stable and prevented the crystallization of the drug (Shapira et al., 2012). The encapsulated drug was not cytotoxic before simulated gastric digestion, but became cytotoxic following digestion with pepsin. The properties of the encapsulation device suggest that the release and the action of the drug might be triggered specifically in the stomach without undesirable effects on oral and/or esophageal epithelia (Shapira et al., 2012).

\section{Encapsulation devices obtained through a "top-down" approach}

The gelling properties and the interfacial activity of the caseins were explored for the encapsulation of bioactive molecules and probiotic bacteria. The probiotic bacteria, Bifidobacterium lactis and Lactobacillus paracasei, were microencapsulated in a casein gel obtained either by the action of transglutaminase (Heidebach et al., 2009b) or rennet (Heidebach et al., 2009a). For the formation of the encapsulation devices, the authors firstly created a water/oil emulsion with an aqueous phase containing the caseins, the probiotics and the selected enzyme. After a reaction time to ensure the complete gelation of the caseins in the aqueous droplets, the encapsulation devices were recovered. Using rennet, encapsulation devices with a diameter of about $68 \mu \mathrm{m}$ were obtained, whereas these were about $165 \mu \mathrm{m}$ in diameter when transglutaminase was used to trigger casein gelation. The encapsulation efficiency ranged between 70 and $100 \%$ and the particles obtained increased the viability of probiotics in simulated gastric conditions (Heidebach et al., 2009a, 2009b).

The ability of sodium caseinate to stabilize oil/water emulsions was also exploited to encapsulate hydrophobic bioactives. The protection of $\beta$-carotene against oxidation was higher in emulsions stabilized by sodium caseinate compared to those stabilized with whey protein isolate (Cornacchia \& Roos, 2011). The authors hypothesized that caseins adsorbed at the oil/water interface chelate potential oxidation inducers such as metal ions and free radicals. Emulsions of fish oil stabilized either by a nonionic surfactant (tween 20), sodium caseinate or hydrogel microspheres of sodium caseinate and pectin cross-linked by transglutaminase were compared for their stability against oxidation (Matalanis, Decker, \& McClements, 2012). Hydrogel microspheres and casein exhibited a superior oxidative stability compared to tween 20-stabilized emulsions, underlining the high antioxidative potential of caseins.

\section{Whey proteins}

\section{Binding properties of whey proteins}

$\beta$-lactoglobulin has been widely studied for its ability to bind hydrophobic and amphiphilic compounds such as flavor compounds, vitamins, fatty acids and polyphenols. Globally, the interactions between $\beta$-lactoglobulin and bioactives are mainly driven by hydrophobic bonds, although hydrogen bonds are also involved in the binding of polyphenols (Zorilla, Liang, Remondetto, \& Subirade, 2011) and fatty acids (Loch et al., 2013). It has been proposed that $\beta$-lactoglobulin binds hydrophobic compounds preferentially in its internal calyx, but additional binding sites in the cavity near to the alpha-helix and the external surface of the $\beta$-barrel have also been described (Kontopidis, Holt, \& Sawyer, 2004).

The parameters of the interaction (localization and number of binding sites on the protein and affinity) depend on the chemical nature of the ligand, the physico-chemical conditions of the medium and the conformation of the protein. The binding affinity constant of curcumin with native $\beta$-lactoglobulin was higher than that with heat-denatured protein (Sneharani, Karakkat, Singh, \& Rao 2010). This change was attributed to a conformational change of the internal calyx of $\beta$-lactoglobulin, resulting in a non-specific binding of curcumin molecules. In contrast, Tavel, Moreau, Bouhallab, Li-Chan, and Guichard (2010) showed that $\beta$-ionone and guaiacol aroma exhibited a higher binding affinity for partially denatured $\beta$-lactoglobulin molecules (molten globule state) than for the native protein. This higher affinity was hypothesized to be due to the exposure of some internal hydrophobic regions on the surface of the partially denatured protein and an increased accessibility of the calyx (Tavel et al., 2010). In some cases, the ligand binding might induce changes in the $\beta$-lactoglobulin structure as reported by Le Maux, Giblin, Croguennec, Bouhallab, and Brodkorb (2012). These authors showed that linoleate binding to $\beta$-lactoglobulin favored denaturation of the protein, with subsequent formation of protein covalent dimers and trimers (Le Maux et al., 2012).

Whey proteins other than $\beta$-lactoglobulin have also been studied for their ability to bind specific ligands. Kuhn, Zhu, Considine, and Singh (2007) showed that BSA has two binding sites and has a higher affinity for 2-nonanone, a flavor compound, than $\beta$-lactoglobulin or $\alpha$-lactalbumin, which only possesses one binding site. After binding to whey proteins, some ligand properties were improved, including, in a non-exhaustive manner: (i) a reduction of UV radiation induced the photo-degradation of folic acid from $40 \%$ to $6 \%$ after $60 \mathrm{~min}$ of treatment (Liang \& Subirade, 2010b); (ii) an increase in the photo-stability and solubility of resveratrol (Liang, Tajmir-Riahi, \& Subirade, 2008) and $\alpha$-tocopherol (Liang, Tremblay-Hébert, \& Subirade, 2011); (iii) an increase in the solubility and half-life of curcumin (Sneharani et al., 2010). In contrast, a decrease in the antioxidant activity of tea catechins was observed when they formed complexes with $\beta$-lactoglobulin (Zorilla et al., 2011) and BSA (Arts et al., 2002). In some cases, the complexes exhibited unexpected new functionalities that were not predictable from those of isolated molecules. This was the case for the complex formed between apo- $\alpha$-lactalbumin (calcium-free form) and oleic acid, known as HAMLET/ BAMLET (human/bovine $\alpha$-lactalbumin made lethal to 
tumor cells), which induces apoptosis of tumor cells (Mok, Pettersson, Orrenius, \& Svanborg, 2007). Heat-denatured $\alpha$ lactalbumin was also able to form a complex with oleic acid that induced apoptosis in cancer cells (Liskova, Kelly, O'Brien, \& Brodkorb, 2010). In addition, a complex formed by $\beta$-lactoglobulin and oleate was shown to induce apoptosis in cancer cells comparable to the activity of BAMLET (Liskova et al., 2011). The improvement in fatty acid solubility through its bonding to these proteins is probably a driving mechanism behind the observed apoptotic effect.

\section{Encapsulation devices obtained through the "bottom-up" approach}

The ability of whey proteins, particularly $\beta$-lactoglobulin, to form nanoparticles used as encapsulating agents has also been extensively studied. Thermal aggregation and desolvation are the main strategies used for the production of these nanoparticles.

Li, Du, Jin, and Du (2012) evaluated the encapsulation efficiency of $\beta$-lactoglobulin nanoparticles for epigallocatechin-3-gallate (EGCG) in a wide range of $\mathrm{pH}(2.5-7.0)$, thermal treatment intensity $\left(30-85^{\circ} \mathrm{C} / 20 \mathrm{~min}\right), \beta$-lactoglobulin concentration $(1-10 \mathrm{mg} / \mathrm{mL})$ and protein:EGCG molar ratio (1:2-1:32). Nanoparticles were formed on heating, concomitantly with the encapsulation of EGCG. The four studied factors affect the nanoparticle characteristics: particle size, zeta potential and entrapment efficiency. The highest protection of EGCG was observed for heat treatment at $85^{\circ} \mathrm{C}$ and a protein:EGCG molar ratio of 1:2 (Li et al., 2012). Nanoparticles protect encapsulated EGCG via steric hindrance and exhibit antioxidative properties due to the free thiols of the heat-denatured proteins (Shpigelman, Israeli, \& Livney, 2010). Similarly, heat-induced $\beta$-lactoglobulin nanoparticles with a diameter less than $50 \mathrm{~nm}$ and a zeta potential of about $-40 \mathrm{mV}$ were produced from $1.0 \% \mathrm{w} / \mathrm{w}$ protein solutions (Shpigelman, Cohen, \& Livney, 2012). These nanoparticles showed an encapsulation efficiency of over 60-70\% for EGCG and according to sensory tests, the bitterness and astringency of EGCG were significantly reduced. The release of EGCG was limited during simulated gastric digestion, which suggests that the nanoparticles could be used to protect EGCG in the stomach, allowing a possible release of the bioactive into the gut (Shpigelman et al., 2012).

High-pressure homogenization was used to produce nanoparticles from heat-induced aggregates of whey proteins for $\boldsymbol{\alpha}$-tocopherol encapsulation (Relkin \& Shukat, 2012). The formed particles exhibited a diameter between 212 and $293 \mathrm{~nm}$, depending on the pressures employed. Compared to homogenization at 300 bar, a pressure at 1200 bar induced some protein structural changes that modified the zeta potential of the produced particles and improved the stability of encapsulated $\alpha$-tocopherol during storage (Relkin \& Shukat, 2012). Alternatively, whey protein nanoparticles with a controlled size were also produced by $\mathrm{pH}$-cycling treatment (acidification and neutralization). Particles with a diameter ranging from 100 to $300 \mathrm{~nm}$ were produced through the acidification of a lowconcentrated solution of heat-denatured whey proteins (Giroux et al., 2010). The whey proteins were linked by covalent bonds in the nanoparticles after the neutralization step. The particle size varied depending on the $\mathrm{pH}$ of acidification (5.0-6.0), aggregation time $(0-75 \mathrm{~h})$ and calcium concentration $(0-5.0 \mathrm{mM})$. Calcium concentration also influenced the voluminosity of the particles: increasing the concentration of calcium decreased the voluminosity of the particles (Giroux et al., 2010). This technique was used to produce particles for entrapping hydrophobic aroma (Giroux \& Britten, 2011). The retention efficiency was maximum when the aroma molecules were added to the protein dispersion before the formation of the particles at pH 5.0 or 5.5 and without added calcium (Giroux \& Britten, 2011).

Nanoparticles of BSA were produced in the presence of the flavonoid quercetin by a desolvation process induced by the addition of $10 \%$ dimethyl sulfoxide (DMSO) (Fang, Jing, et al., 2011). These nanoparticles showed a zeta potential of $-12.5 \mathrm{mV}$ and a diameter close to $10 \mathrm{~nm}$, surprisingly smaller than the diameter measured for native BSA and for the nanoparticles produced in the absence of the flavonoid (Fang, Hao, et al., 2011; Fang, Jing, et al., 2011). Based on transmission electron microscopy observations, the authors explained their results by the highest compaction of the nanoparticles in complexes with the flavonoid (Fang, Jing, et al., 2011). The antioxidant activity of encapsulated flavonoid was not substantially changed, but its stability under intestinal conditions appeared to increase. The latter observation was attributed to the formation of both hydrophobic interactions and hydrogen bonds between quercetin and BSA during the encapsulation process (Fang, Hao, et al., 2011). Desolvation was also used to produce nanoparticles of $\beta$-lactoglobulin for curcumin encapsulation at alkaline $\mathrm{pH}$ using acetone (Sneharani et al., 2010). The formed nanoparticles were stabilized using glutaraldehyde as a cross-linking agent (Gunasekaran et al., 2007). Spherical particles with a diameter of $140 \mathrm{~nm}$ were obtained, which showed a curcumin encapsulation efficiency of about 96\%, with a simultaneous increase in curcumin solubility in aqueous solution from 0.03 to $\approx 620 \mu \mathrm{M}$. However, the encapsulated curcumin was slowly released from protein nanoparticles at neutral $\mathrm{pH}$, which limits the use of these nanoparticles as a vehicle for such substances (Sneharani et al., 2010).

To develop nanoparticles designed for food applications, i.e., without the use of non-food grade solvents and chemical cross-linking agents, Gulseren et al. (2012a) tailored nanoparticles of whey protein isolate (WPI) by desolvation using ethanol. These particles were used for the encapsulation of zinc and demonstrated an entrapment efficiency between 80 and $100 \%$, with a maximum incorporation of zinc of about $8 \mathrm{mg} / \mathrm{g}$ WPI. These particles remained stable for 30 days at $22{ }^{\circ} \mathrm{C}$ at $\mathrm{pH} 3.0$ (Gulseren et al., 2012b). Another 
food-grade technology for the encapsulation of bioactives based on the supercritical drying of preformed hydrogels to form aerogels was applied with success to WPI (Betz, Garcia-Gonzalez, Subrahmanyam, Smirnova, \& Kulozik, 2012). Aerogels formed by controlled drying with supercritical carbon dioxide of WPI hydrogels exhibit a mesoporous structure with a high encapsulation capacity of ketoprofen, a hydrophobic molecule, compared to the macroporous structure found for cryogels formed by conventional freeze drying techniques. Hence, similar to polysaccharides, protein aerogels with a high encapsulating efficiency offer new possibilities as an alternative to aerogels from synthetic polymers.

\section{Encapsulation devices obtained from a "top-down" approach}

Top-down approaches for the encapsulation of bioactives using whey proteins are basically restricted to strategies of protein cold gelation, the formation of emulsions or a combination of these two strategies using extrusion techniques. Remondetto, Paquin, and Subirade (2002) reported that cold-set gels of $\beta$-lactoglobulin induced by the addition of iron show different morphologies, depending on the iron/protein ratio. For the lower ratios tested, filamentous gels were formed, whereas particulate gels were obtained at high ratios (Remondetto et al., 2002). Particulate gels are mainly stabilized by van der Waals interactions; the large concentration of iron causes a rapid decrease in the repulsive forces, which generates random aggregation and leads to particulate gels. Moreover, low concentrations of iron mainly drive the formation of gels via hydrophobic interactions; the low iron concentration causes a decrease in the surface charge of the molecules and/or aggregates, facilitating interaction between exposed hydrophobic regions, which orients the growth of the assembly in only one direction, leading to filaments (Remondetto \& Subirade, 2003). The microstructure of the gels affects the iron release properties. At acidic $\mathrm{pH}$, iron was released more efficiently from particulate gels than from filamentous gels. In contrast, iron release was more efficient with filamentous gels at neutral $\mathrm{pH}$, providing greater iron absorption under intestinal conditions, according to in vitro tests. This suggests that filamentous matrices are more efficient in the protection and transport of iron for nutritional purposes (Remondetto, Beyssac, \& Subirade, 2004).

Although the fragmentation of protein hydrogels into particles characterizes the top-down approach, some authors limit their research to the ability of gels to entrap and release bioactives, without the stage of gel fragmentation into particles. Nevertheless, some papers describe the production of particles from hydrogels, which characterizes a real application of the top-down approach. Therefore, Martin and de Jong (2012b) investigated the effect of $\mathrm{pH}$ and pre-heating conditions on iron-induced cold-set gels of WPI. After gelation, gels were refined into particles; both the stability of the particles and the iron-release kinetic were evaluated. The structural characteristics and the stability of the particles changed according to the severity of the pre-heating treatment. In this study, the iron:protein molar ratio in the particles was controlled by the duration of pre-heating at $80{ }^{\circ} \mathrm{C}$, reaching 5.3:1, 8.8:1 and about $17: 1$ after $0.5,3 \mathrm{~h}, 10 \mathrm{~h}$ of pre-heating, respectively. However, irrespective of the conditions of preheating, the same iron-release kinetic was observed at acidic pH (Martin \& de Jong, 2012b). The preparation of protein particles for the simultaneous encapsulation of ferrous iron and ascorbate that protects iron against oxidation was also reported (Martin \& de Jong, 2012a). The particles had a mean diameter of 850 and $75 \mu \mathrm{m}$ before and after lyophilization, respectively. The iron/protein molar ratio in the particles was approximately 5.7:1.0. The In vitro bio-accessibility of $\mathrm{Fe}^{2+}$ doubled following its encapsulation into protein particles and even increased from $10 \%$ to $80 \%$ in the presence of ascorbate (Martin \& de Jong, 2012a). These authors proposed that whey protein particles combined with ascorbate can be adequately used to fortify food products with iron. Cold-set gelation was also used to encapsulate microorganisms of interest. Reid et al. (2005) and Hebrard et al. (2006) used calcium-induced cold-set gelation to encapsulate probiotic bacteria and recombinant yeast, respectively. The protocol used is basically summarized by the dispersion of the selected cell cultures in a heat-treated WPI solution, followed by extrusion of the mixture in a solution of calcium chloride. The contact with the calcium solution induced the gelation of the proteins and consequently, the formation of capsules entrapping the probiotics (Hebrard et al., 2006; Reid et al., 2005). A SEM image of Lactobacillus rhamnosus cells homogeneously entrapped in the network of WPI capsules is shown in Fig. 3. The formed capsules possessed a diameter of about $3.0 \mathrm{~mm}$ and were an effective protective barrier for

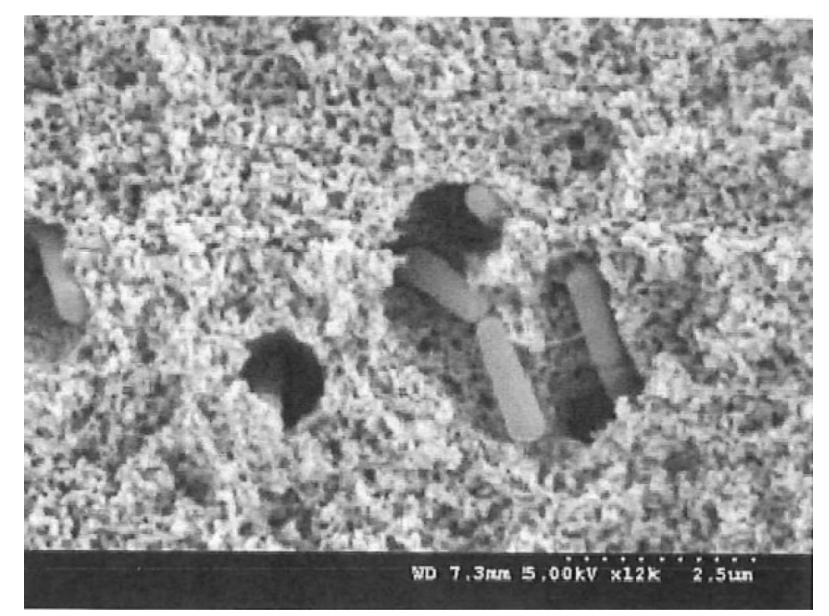

Fig. 3. SEM cross-section image $(12,000 \times$ magnification) of a whey protein-isolate gel with encapsulated Lactobacillus rhamnosus (adapted from Reid et al., 2005). 
the encapsulated cells against gastric digestion conditions (Hebrard et al., 2006; Reid et al., 2005). Similarly, Doherty et al. (2011) produced capsules of about $200 \mu \mathrm{m}$ in diameter from heat-treated WPI that were dropped in an acetate buffer solution at $\mathrm{pH} 4.6$ for gelation. These capsules were used for the encapsulation of L. rhamnosus. In these studies, the encapsulation efficiency of the bacteria reached $96 \%$. Indeed, the encapsulation device increased the viability of the cells during storage and their resistance against gastric digestion. Hence, whey proteins constitute an ideal biopolymer for the encapsulation and protection of probiotics and their challenging delivery to intestinal absorption sites (Doherty et al., 2011).

Betz and Kulozik (2011) used WPI heat-set gels for the encapsulation of anthocyanins. The gels were formed by heating an acidified WPI solution ( $\mathrm{pH} 3.0$ and 1.5) containing the bioactive. They were evaluated for their stability and the kinetics of release of the encapsulated compound in simulated gastric fluid. The authors showed that the $\mathrm{pH}$ of the WPI solution affected the interaction between anthocyanins and the proteins. Gels formed at $\mathrm{pH} 1.5$ were more stable than those formed at $\mathrm{pH} 3.0$, representing a very favorable microenvironment for the encapsulation of anthocyanins (Betz \& Kulozik, 2011). The adsorption ability of heat-denatured proteins at an oil/water interface and their subsequent gelation has been explored, to stabilize emulsions with the aim of forming delivery systems. Hence, the interfacial properties of whey proteins are a key element explored for the encapsulation of various compounds. Immediately after the formation of the emulsion by mixing heat-denatured WPI solution and soybean oil containing retinol, the lipid droplets were extruded into a calcium chloride solution to induce gelation of interfacial proteins (Beaulieu, Savoie, Paquin, \& Subirade, 2002). The thusformed encapsulating devices were about $2.0 \mathrm{~mm}$ in diameter and were stabilized by intermolecular $\beta$-sheet structures between protein molecules (Beaulieu et al., 2002). With the same objective, Liang, Leung Sok Line, Remondetto, and Subirade (2010) produced an emulsion containing $\alpha$-tocopherol stabilized by an interfacial layer formed by the calcium-induced cold-set gelation of predenatured $\beta$-lactoglobulin. After in vitro enzymatic digestion of the encapsulating devices, the authors showed that the release of the bioactive is mainly controlled by the kinetics of protein hydrolysis. In addition, $\alpha$-tocopherol released during the digestion process is degraded more slowly than free $\alpha$-tocopherol, probably due to the protection effect provided by its interaction with the predenatured proteins and/or produced peptides (Liang et al., 2010). Cornacchia and Roos (2011) used whey proteins to stabilize oil in water emulsions to produce delivery systems capable of protecting and transporting $\beta$-carotene. Similarly, Tippetts, Martini, Brothersen, and McMahon (2012) produced emulsions stabilized with whey proteins to generate stable delivery systems for vitamin $\mathrm{D}_{3}$-enriched cheeses.

\section{Supra-molecular structures with putative} encapsulation properties

In addition to the production of the encapsulation devices presented above, milk proteins can spontaneously form a large variety of supra-molecular structures under specific physico-chemical conditions. The supra-molecular structures differ in geometry, size and porosity. The main factors that drive the final structure are: protein conformation and concentration, $\mathrm{pH}$, temperature, ionic strength and the presence of small solutes (Bouhallab \& Croguennec, 2014). The supra-molecular structures described in the literature are mainly fibrils (Loveday, Wang, Rao, Anema, \& Singh, 2012), ribbons (Lara, Adamcik, Jordens, \& Mezzenga, 2011), spherulites (Domike, Hardin, Armstead, \& Donald, 2009), nanotubes (GravelandBikker \& de Kruif, 2006) and microspheres (Nigen, Croguennec, \& Bouhallab, 2009; Nigen, Croguennec, Renard, \& Bouhallab, 2007). Amyloid-type fibrils are linear polymers that are between 3 and $10 \mathrm{~nm}$ in width, and can reach several microns in length (Loveday et al., 2012). The formation of fibers involves two steps: nucleation and subsequent unidirectional growth (Arnaudov, de Vries, Ippel, \& van Mierlo, 2003). The ability to form fibers has been described for $\beta$-lactoglobulin (Loveday et al., 2012) and $\alpha$-lactalbumin (Goers, Permyakov, Permyakov, Uversky, \& Fink, 2002). Specific physico-chemical conditions are generally required to initiate fibrillation; the proteins have to contain exposed hydrophobic regions and to conserve some surface charges (Bouhallab \& Croguennec, 2014). In addition, the fibrillation process is favored by the cleavage of some peptide bonds (Akkermans et al., 2008). These fibers can further self-associate into more complex structures, e.g., ribbons and spherulites. Ribbons are the result of the lateral stacking of these fibers and are usually obtained after the prolonged heating of globular proteins under acidic conditions (Lara et al., 2011). Alternatively, spherulites are formed by the radial association of the fibers, a structure that can reach hundreds of micrometers in diameter (Domike et al., 2009). The formation of nanotubes from milk proteins is less widespread than the formation of fibers or aggregates. To date, milk protein nanotubes have only been obtained by the self-assembly of $\alpha$-lactalbumin fragments formed by limited hydrolysis of the protein backbone by a serine protease (GravelandBikker \& de Kruif, 2006). Regular nanotubes with a length up to several microns, an external diameter of $20 \mathrm{~nm}$ and an internal diameter of about $8 \mathrm{~nm}$ can be obtained by adjusting the protein concentration, the concentration of added specific divalent cations and hydrolysis conditions (Graveland-Bikker \& de Kruif, 2006). It was suggested that the reversible association of $\alpha$-lactalbumin into nanotubes could be explored as vehicles for delivering bioactives and for encapsulation and release purposes (Ipsen \& Otte, 2007). The spontaneous formation of nano- and microspheres was reported for mixed oppositely charged proteins (Bouhallab \& Croguennec, 2014). The formation of 
microspheres between positively charged lysozyme and negatively charged $\alpha$-lactalbumin and the underlying mechanisms are now well described (Nigen et al., 2009, 2007). The microspheres are obtained by controlling the protein concentration and conformation, the protein molar ratio, temperature, $\mathrm{pH}$ and ionic strength. Slightly altering the conditions affects the morphology of the resulting supramolecular structures, which change from well-ordered nano- or microspheres to amorphous aggregates. The ability to form microspheres during the co-assembly of other oppositely charged proteins has been studied. Considering only milk proteins, we demonstrated the formation of microspheres by the co-assembly of lactoferrin with either $\beta$-lactoglobulin, $\alpha$-lactalbumin or BSA under specific experimental conditions (unpublished data). de Kruif, Pedersen, Huppertz, and Anema (2013) reported the formation of reversible complexes, called coacervates, between structured, positively charged lactotransferrin and unstructured, negatively charged $\beta$ or k-casein. However, the spherical nature of the formed complexes was not directly demonstrated. In a systematic study conducted on milk proteins and proteins from other sources, we showed that nanoand/or microspheres can be generated in all binary mixtures containing oppositely charged proteins, once the experimental conditions and protein stoichiometry have been optimized. In contrast to protein assembly induced by severe conditions (mainly heat treatment), the assembly under mild conditions allows the formation of suprastructures that are exclusively stabilized by non-covalent interactions. This ensures a better control of both assembly and disassembly processes, which is essential when the controlled release of bioactives is required.

Although several authors have indicated that these supra-structures could be of potential interest as encapsulation agents, no publications have described effective applications to date. This new research area of controlled coassembly between mixed proteins offers new opportunities to develop innovative, reversible and versatile vehicles to encapsulate bioactive or sensitive ingredients.

\section{Concluding remarks}

Encapsulation technologies that have been used for a long time in the pharmaceutical industry for drug delivery applications offer a real opportunity for the food industry. Encapsulation represents a means to develop innovative products to satisfy the growing demand of the consumer for foods with health and well-being benefits and is now widely used to stabilize food ingredients, increase flavor retention or to mask undesirable flavors. For some food applications, encapsulation can be performed using relatively simple operations, such as emulsions, suspensions, gels, and solid matrices. Due to their high abundance, nutritional value and high acceptance by consumers, milk proteins have largely been tested to design encapsulation devices, owing to their versatility and excellent functional properties. Hydrophobic vitamins, polyphenols, flavorings, fatty acids, cells, and minerals are among encapsulated bioactives. At the laboratory scale, milk proteins are effective in protecting bioactives against oxidation and photodegradation, increasing their solubility, and in maintaining the viability of probiotic cells. Traditional encapsulation technologies have been applied to milk proteins, including spray drying, freeze drying, extrusion and coacervation. However, despite the success on a laboratory scale, these technologies applied to proteins as encapsulation devices still present limitations and difficulties for the large-scale production of food-grade microencapsulated substances. Hence, the up-scaling of laboratory results remains a research challenge. For food applications, a further challenge is to ensure that sensitive molecules can be entrapped in a form that is physically and chemically compatible with the food matrix without adverse effects. Also, the use of milk proteins for the targeted delivery of food bioactives or for increasing nutrient bioavailability remains an emerging research area.

Encapsulation via novel technologies constitutes another issue for future research. The trend is toward a reduction in particle size with a special interest in developing techniques such as electrospraying and electrospinning of proteins for the production of nanosized particles. Another field to explore is the encapsulating potentialities of spontaneously co- or self-assembled supra-molecular structures: native casein micelles, $\alpha$-lactalbumin nanotubes, $\beta$-lactoglobulin fibers, and nanospheres from oppositely charged proteins. The fact that these nanoparticles are tailored from natural and edible polymers, without the use of exogenous additives, makes them promising as building blocks for encapsulation, offering several associated innovations and advantages:

- There is no need for extended research to prove the safety and non-cytotoxicity of co-assembled milk proteins.

- They constitute a relevant alternative for nanoparticles composed of lipids, which require the use of organic solvents or surfactants for their fabrication.

- They constitute a relevant response to meet the growing demand for additive-free foods. For example, they can be used as encapsulating materials in infant formulas, a market with spectacular global growth. The annual growth of the worldwide production of infant formulas, estimated at $11 \%$ from 2010 to 2014 , is predicted to increase to over $20 \%$ due the very rapid growth of the Asiatic market (Blanchard, Zhu, \& Schuck, 2013).

- Their reversibility allows controlled disassembly, a fundamental step for targeted release.

Before suggested applications are implemented, fundamental research to better control milk protein coassembly into nano-microspheres is needed - in particular concerning: (i) assembly and disassembly mechanisms in the presence of bioactives and (ii) the stability of formed 
supra-molecular structures toward processing and storage conditions either on their own or incorporated within food matrices. For some application purposes, it would be necessary to tailor and stabilize these structures using, for instance, food-grade cross-linkers. Due to their edibility, milk proteins and their multiple assemblies constitute ideal drug carriers for an oral-delivery system and several pharmaceutical projects are already ongoing.

\section{Acknowledgments}

We warmly thank our collaborators M. Nigen, D. Salvatore and P. Hamon for their contributions. Financial support from the federal Brazilian funding agency CNPq and INRA is acknowledged.

\section{References}

Abd El-Salam, M. H., \& El-Shibiny, S. (2012). Formation and potential uses of milk proteins as nano delivery vehicles for nutraceuticals: a review. International Journal of Dairy Technology, 65, 13-21.

Aberkane, L., Jasniewski, J., Gaiani, C., Hussain, R., Scher, J., \& Sanchez, C. (2012). Structuration mechanism of $\beta$-lactoglobulin acacia gum assemblies in presence of quercetin. Food Hydrocolloids, 29, 9-20.

Akkermans, C., Venema, P., van der Goot, A. J., Gruppen, H., Bakx, E. J., Boom, R. M., et al. (2008). Peptides are building blocks of heat-induced fibrillar protein aggregates of beta-lactoglobulin formed at pH 2. Biomacromolecules, 9, 1474-1479.

Alting, A. C., de Jongh, H. H., Visschers, R. W., \& Simons, J. W. (2002). Physical and chemical interactions in cold gelation of food proteins. Journal of Agricultural and Food Chemistry, 50, 4682-4689.

Anema, S. G., \& de Kruif, C. G. (2011). Interaction of lactoferrin and lysozyme with casein micelles. Biomacromolecules, 12, 3970-3976.

Anema, S. G., \& de Kruif, C. G. (2012). Lactoferrin binding to transglutaminase cross-linked casein micelles. International Dairy Journal, 26, 83-87.

Arnaudov, L. N., de Vries, R., Ippel, H., \& van Mierlo, C. P. (2003). Multiple steps during the formation of beta-lactoglobulin fibrils. Biomacromolecules, 4, 1614-1622.

Arts, M. J. T. J., Haenen, G. R. M. M., Wilms, L. C., Beetstra, S. A. J. N., Heijnen, C. G. M., Voss, H. P., et al. (2002). Interactions between flavonoids and proteins: effect on the total antioxidant capacity. Journal of Agricultural and Food Chemistry, 50, 1184-1187.

Augustin, M. A., \& Sanguansri, L. (2008). Encapsulation of bioactives. In J. M. Aguilera, \& P. J. Lillforrd (Eds.), Food materials sciencePrinciples and practice (pp. 577-601). New York: Springer.

Beaulieu, L., Savoie, L., Paquin, P., \& Subirade, M. (2002). Elaboration and characterization of whey protein beads by an emulsification/ cold gelation process: application for the protection of retinol. Biomacromolecules, 3, 239-248.

Bengoechea, C., Peinado, I., \& McClements, D. J. (2011). Formation of protein nanoparticles by controlled heat treatment of lactoferrin: factors affecting particle characteristics. Food Hydrocolloids, 25, 1354-1360.

Benshitrit, R. C., Levi, C. S., Tal, S. L., Shimoni, E., \& Lesmes, U. (2012). Development of oral food-grade delivery systems: current knowledge and future challenges. Food \& Function, 3, 10-21.

Betz, M., Garcia-Gonzalez, C. A., Subrahmanyam, R. P., Smirnova, I., \& Kulozik, U. (2012). Preparation of novel whey protein-based aerogels as drug carriers for life science applications. Journal of Supercritical Fluids, 72, 111-119.
Betz, M., \& Kulozik, U. (2011). Whey protein gels for the entrapment of bioactive anthocyanins from bilberry extract. International Dairy Journal, 21, 703-710.

Blanchard, E., Zhu, P., \& Schuck, P. (2013). Infant formula powders. In B. Bhandari, N. Bansal, M. Zhang, \& P. Schuck (Eds.), Handbook of food powders: Process and properties (pp. 465-483). Cambridge: Woodhead Publishing.

Bohin, M. C., Vincken, J. P., van der Hijden, H. T., \& Gruppen, H. (2012). Efficacy of food proteins as carriers for flavonoids. Journal of Agricultural and Food Chemistry, 60, 4136-4143.

Bouhallab, S., \& Croguennec, T. (2014). Spontaneous assembly and induced aggregation of food proteins. Advances in Polymer Science, 256, 67-101.

Bovetto, L., Schmitt, C. J. E., Beaulieu, M., Carlier, N., \& Unterhaslberger, G. (2007). Nanoparticulated whey proteins. European Patent Office, EP 1799046 A2.

Chen, L., Remondetto, G. E., \& Subirade, M. (2006). Food proteinbased materials as nutraceutical delivery systems. Trends in Food Science \& Technology, 17, 272-283.

Chen, H. D., Weiss, J. C., \& Shahidi, F. (2006). Nanotechnology in nutraceuticals and functional foods. Food Technology, 60, 30-36.

Cornacchia, L., \& Roos, Y. H. (2011). Stability of beta-carotene in protein-stabilized oil-in-water delivery systems. Journal of Agricultural and Food Chemistry, 59, 7013-7020.

Croguennec, T., Li, N., Phelebon, L., Garnier-Lambrouin, F., \& GesanGuiziou, G. (2012). Interaction between lactoferrin and casein micelles in skimmed milk. International Dairy Journal, 27, 34-39.

Danino, D., Livney, Y. D., Ramon, O., Portnoy, I., \& Cogan, U. (2011). Beta-casein assemblies for enrichment of food and beverages and methods for preparation thereof. United States Patent, US 2011/ 0038987 A1.

Desfougeres, Y., Croguennec, T., Lechevalier, V., Bouhallab, S., \& Nau, F. (2010). Charge and size drive spontaneous self-assembly of oppositely charged globular proteins into microspheres. Journal of Physical Chemistry B, 114, 4138-4144.

Diarrassouba, F., Remondetto, G., Liang, L., Garrait, G., Beyssac, E., \& Subirade, M. (2013). Effects of gastrointestinal pH conditions on the stability of the $\beta$-lactoglobulin/vitamin D3 complex and on the solubility of vitamin D3. Food Research International, 52, 515-521.

Doherty, S. B., Gee, V. L., Ross, R. P., Stanton, C., Fitzgerald, G. F., \& Brodkorb, A. (2011). Development and characterisation of whey protein micro-beads as potential matrices for probiotic protection. Food Hydrocolloids, 25, 1604-1617.

Domike, K. R., Hardin, E., Armstead, D. N., \& Donald, A. M. (2009). Investigating the inner structure of irregular beta-lactoglobulin spherulites. European Physical Journal E, 29, 173-182.

Doshi, J., \& Reneker, D. H. (1995). Electrospinning process and applications of electrospun fibers. Journal of Electrostatics, 35, $151-160$.

Elzoghby, A. O., El-Fotoh, W. S., \& Elgindy, N. A. (2011). Caseinbased formulations as promising controlled release drug delivery systems. Journal of Controlled Release, 153, 206-216.

Esmaili, M., Ghaffari, S. M., Moosavi-Movahedi, Z., Atri, M. S., Sharifizadeh, A., Farhadi, M., et al. (2011). Beta casein-micelle as a nano vehicle for solubility enhancement of curcumin; food industry application. LWT - Food Science and Technology, 44, 2166-2172.

Fang, R., Hao, R., Wu, X., Li, Q., Leng, X., \& Jing, H. (2011). Bovine serum albumin nanoparticle promotes the stability of quercetin in simulated intestinal fluid. Journal of Agricultural and Food Chemistry, 59, 6292-6298.

Fang, R., Jing, H., Chai, Z., Zhao, G., Stoll, S., Ren, F., et al. (2011). Design and characterization of protein-quercetin bioactive nanoparticles. Journal of Nanobiotechnology, 9(19), 1-14.

Farrell, H. M., Malin, E. L., Brown, E. M., \& Qi, P. X. (2006). Casein micelle structure: what can be learned from milk synthesis and 
structural biology? Current Opinion in Colloid \& Interface Science, 11, 135-147.

Gelamo, E. L., Silva, C. H., Imasato, H., \& Tabak, M. (2002). Interaction of bovine (BSA) and human (HSA) serum albumins with ionic surfactants: spectroscopy and modelling. Biochimica et Biophysica Acta, 1594, 84-99.

Gibbs, B. F., Kermasha, S., Alli, I., \& Mulligan, C. N. (1999). Encapsulation in the food industry: a review. International Journal of Food Science and Nutrition, 50, 213-224.

Giroux, H. J., \& Britten, M. (2011). Encapsulation of hydrophobic aroma in whey protein nanoparticles. Journal of Microencapsulation, 28, 337-343.

Giroux, H. J., Houde, J., \& Britten, M. (2010). Preparation of nanoparticles from denatured whey protein by $\mathrm{pH}$-cycling treatment. Food Hydrocolloids, 24, 341-346.

Goers, J., Permyakov, S. E., Permyakov, E. A., Uversky, V. N., \& Fink, A. L. (2002). Conformational prerequisites for alphalactalbumin fibrillation. Biochemistry, 41, 12546-12551.

Gong, J., Huo, M., Zhou, J., Zhang, Y., Peng, X., Yu, D., et al. (2009) Synthesis, characterization, drug-loading capacity and safety of novel octyl modified serum albumin micelles. International Journal of Pharmaceutics, 376, 161-168.

Gouin, S. (2004). Microencapsulation: industrial appraisal of existing technologies and trends. Trends in Food Science \& Technology, 15, 330-347.

Graveland-Bikker, J. F., \& de Kruif, C. G. (2006). Unique milk protein based nanotubes: food and nanotechnology meet. Trends in Food Science \& Technology, 17, 196-203.

Gulseren, I., Fang, Y., \& Corredig, M. (2012a). Whey protein nanoparticles prepared with desolvation with ethanol: characterization, thermal stability and interfacial behavior. Food Hydrocolloids, 29, 258-264.

Gulseren, I., Fang, Y., \& Corredig, M. (2012b). Zinc incorporation capacity of whey protein nanoparticles prepared with desolvation with ethanol. Food Chemistry, 135, 770-774.

Gunasekaran, S., Ko, S., \& Xiao, L. (2007). Use of whey proteins for encapsulation and controlled delivery applications. Journal of Food Engineering, 83, 31-40.

Gutiérrez, F. J., Albillos, S. M., Casas-Sanz, E., Cruz, Z., GarcíaEstrada, C., García-Guerra, A., et al. (2013). Methods for the nanoencapsulation of $\beta$-carotene in the food sector. Trends in Food Science \& Technology, 32, 73-83.

Haham, M., Ish-Shalom, S., Nodelman, M., Duek, I., Segal, E., Kustanovich, M., et al. (2012). Stability and bioavailability of vitamin D nanoencapsulated in casein micelles. Food \& Function, 3, 737-744.

Hebrard, G., Blanquet, S., Beyssac, E., Remondetto, G., Subirade, M., \& Alric, M. (2006). Use of whey protein beads as a new carrier system for recombinant yeasts in human digestive tract. Journal of Biotechnology, 127, 151-160.

Heidebach, T., Forst, P., \& Kulozik, U. (2009a). Microencapsulation of probiotic cells by means of rennet-gelation of milk proteins. Food Hydrocolloids, 23, 1670-1677.

Heidebach, T., Forst, P., \& Kulozik, U. (2009b). Transglutaminaseinduced caseinate gelation for the microencapsulation of probiotic cells. International Dairy Journal, 19, 77-84.

Hemar, Y., Cheng, L. J., Oliver, C. M., Sanguansri, L., \& Augustin, M. (2010). Encapsulation of resveratrol using water-in-oil-in-water double emulsions. Food Biophysics, 5, 120-127.

Hernández, H., Tübke, A., Soriano, F. H., Vezzani, A., Amoroso, S., \& Dosso, M. (2013). The 2013 EU industrial R\&D investment scoreboard. Available from: http://iri.jrc.ec.europa.eu/documents/ 10180/99853/The\%202013\%20EU\%20Industrial\%20R\%26D\% 20Investment\%20Scoreboard Accessed February 2014.

Hong, G. P., Surassmo, S., Chun, J. Y., Min, S. G., \& Choi, M. J. (2012). Influence of high hydrostatic pressure on the capsicum oleoresin encapsulated by globular protein. International Journal of Food Engineering, 8, Article 16.

Ipsen, R., \& Otte, J. (2007). Self-assembly of partially hydrolysed alpha-lactalbumin. Biotechnology Advances, 25, 602-605.

Ko, S., \& Gunasekaran, S. (2006). Preparation of sub-100-nm betalactoglobulin (BLG) nanoparticles. Journal of Microencapsulation, 23, 887-898.

Kontopidis, G., Holt, C., \& Sawyer, L. (2004). Beta-lactoglobulin: binding properties, structure, and function. Journal of Dairy Science, 87, 785-796.

de Kruif, C. G., Pedersen, J., Huppertz, T., \& Anema, S. G. (2013). Coacervates of lactotransferrin and beta- or kappa-casein: structure determined using SAXS. Langmuir, 29, 10483-10490.

Kuhn, J., Zhu, X. Q., Considine, T., \& Singh, H. (2007). Binding of 2 nonanone and milk proteins in aqueous model systems. Journal of Agricultural and Food Chemistry, 55, 3599-3604.

Lara, C., Adamcik, J., Jordens, S., \& Mezzenga, R. (2011). General self-assembly mechanism converting hydrolyzed globular proteins into giant multistranded amyloid ribbons. Biomacromolecules, 12, 1868-1875.

Le Maux, S., Giblin, L., Croguennec, T., Bouhallab, S., \& Brodkorb, A. (2012). Beta-lactoglobulin as a molecular carrier of linoleate: characterization and effects on intestinal epithelial cells in vitro. Journal of Agricultural and Food Chemistry, 60, 9476-9483.

Li, B., Du, W., Jin, J., \& Du, Q. (2012). Preservation of (-)-epigallocatechin-3-gallate antioxidant properties loaded in heat treated beta-lactoglobulin nanoparticles. Journal of Agricultural and Food Chemistry, 60, 3477-3484.

Liang, L., Leung Sok Line, V., Remondetto, G. E., \& Subirade, M. (2010). In vitro release of $\alpha$-tocopherol from emulsion-loaded $\beta$ lactoglobulin gels. International Dairy Journal, 20, 176-181.

Liang, L., \& Subirade, M. (2010). Beta-lactoglobulin/folic acid complexes: formation, characterization, and biological implication. Journal of Physical Chemistry B, 114, 6707-6712.

Liang, L., Tajmir-Riahi, H. A., \& Subirade, M. (2008). Interaction of beta-lactoglobulin with resveratrol and its biological implications. Biomacromolecules, 9, 50-56.

Liang, L., Tremblay-Hébert, V., \& Subirade, M. (2011). Characterisation of the $\beta$-lactoglobulin/ $\alpha$-tocopherol complex and its impact on $\alpha$ tocopherol stability. Food Chemistry, 126, 821-826.

Liskova, K., Auty, M. A. E., Chaurin, V., Min, S., Mok, K. H., O'Brien, N., et al. (2011). Cytotoxic complexes of sodium oleate with beta-lactoglobulin. European Journal of Lipid Science and Technology, 113, 1207-1218.

Liskova, K., Kelly, A. L., O’Brien, N., \& Brodkorb, A. (2010). Effect of denaturation of alpha-lactalbumin on the formation of BAMLET (bovine alpha-lactalbumin made lethal to tumor cells). Journal of Agricultural and Food Chemistry, 58, 4421-4427.

Livney, Y. D. (2010). Milk proteins as vehicles for bioactives. Current Opinion in Colloid \& Interface Science, 15, 73-83.

Livney, Y. D., \& Dalgleish, D. G. (Patent). Casein micelles for nanoencapsulation of hydrophobic compounds. United States Patent, US 2009/0311329 A1.

Loch, J. I., Bonarek, P., Polit, A., Riès, D., DziedzickaWasylewska, M., \& Lewiński, K. (2013). Binding of 18-carbon unsaturated fatty acids to bovine $\beta$-lactoglobulin-structural and thermodynamic studies. International Journal of Biological Macromolecules, 57, 226-231.

López-Rubio, A., \& Lagaron, J. M. (2012). Whey protein capsules obtained through electrospraying for the encapsulation of bioactives. Innovative Food Science \& Emerging Technologies, 13, 200-206.

López-Rubio, A., Sanchez, E., Wilkanowicz, S., Sanz, Y., \& Lagaron, J. M. (2012). Electrospinning as a useful technique for the encapsulation of living bifidobacteria in food hydrocolloids. Food Hydrocolloids, 28, 159-167. 
Loveday, S. M., Wang, X. L., Rao, M. A., Anema, S. G., \& Singh, H. (2012). $\beta$-Lactoglobulin nanofibrils: effect of temperature on fibril formation kinetics, fibril morphology and the rheological properties of fibril dispersions. Food Hydrocolloids, 27, 242-249.

Ma, W., Baron, A., Guyot, S., Bouhallab, S., \& Zanchi, D. (2012). Kinetics of the formation of beta-casein/tannin mixed micelles. RSC Advances, 2, 3934-3941.

Martin, A. H., \& de Jong, G. A. (2012a). Enhancing the in vitro Fe(2+) bio-accessibility using ascorbate and cold-set whey protein gel particles. Dairy Science \& Technology, 92, 133-149.

Martin, A. H., \& de Jong, G. A. H. (2012b). Impact of protein pretreatment conditions on the iron encapsulation efficiency of whey protein cold-set gel particles. European Food Research and Technology, 234, 995-1003.

Matalanis, A., Decker, E. A., \& McClements, D. J. (2012). Inhibition of lipid oxidation by encapsulation of emulsion droplets within hydrogel microspheres. Food Chemistry, 132, 766-772.

Matalanis, A., \& McClements, D. J. (2013). Hydrogel microspheres for encapsulation of lipophilic components: optimization of fabrication \& performance. Food Hydrocolloids, 31, 15-25.

Mok, K. H., Pettersson, J., Orrenius, S., \& Svanborg, C. (2007). HAMLET, protein folding, and tumor cell death. Biochemical and Biophysical Research Communications, 354, 1-7.

Nigen, M., Croguennec, T., \& Bouhallab, S. (2009). Formation and stability of alpha-lactalbumin-lysozyme spherical particles: involvement of electrostatic forces. Food Hydrocolloids, 23, $510-518$

Nigen, M., Croguennec, T., Renard, D., \& Bouhallab, S. (2007). Temperature affects the supramolecular structures resulting from alpha-lactalbumin-lysozyme interaction. Biochemistry, 46, $1248-1255$.

Raouche, S., Dobenesque, M., Bot, A., Lagaude, A., \& Marchesseau, S. (2009). Casein micelles as a vehicle for iron fortification of foods. European Food Research and Technology, 229, 929-935.

Raouche, S., Naille, S., Dobenesque, M., Bot, A., Jumas, J. C., Cuq, J. L., et al. (2009). Iron fortification of skim milk: minerals and Fe-57 Mossbauer study. International Dairy Journal, 19, 56-63.

Reid, A. A., Vuillemard, J. C., Britten, M., Arcand, Y., Farnworth, E., \& Champagne, C. P. (2005). Microentrapment of probiotic bacteria in a $\mathrm{Ca} 2+$-induced whey protein gel and effects on their viability in a dynamic gastro-intestinal model. Journal of Microencapsulation, 22, 603-619.

Relkin, P., \& Shukat, R. (2012). Food protein aggregates as vitaminmatrix carriers: impact of processing conditions. Food Chemistry, $134,2141-2148$.

Remondetto, G. E., Beyssac, E., \& Subirade, M. (2004). Iron availability from whey protein hydrogels: an in vitro study. Journal of Agricultural and Food Chemistry, 52, 8137-8143.

Remondetto, G. E., Paquin, P., \& Subirade, M. (2002). Cold gelation of beta-lactoglobulin in the presence of iron. Journal of Food Science, 67, 586-595.

Remondetto, G. E., \& Subirade, M. (2003). Molecular mechanisms of Fe2+-induced beta-lactoglobulin cold gelation. Biopolymers, 69, 461-469.

Sahlan, M., \& Pramadewi, I. (2012). Nanoencapsulation of the flavonoids isolated from Phaleria macrocarpa leaf by casein micelle. International Journal of Pharmacology and Biological Sciences, 3, 472-478.

Saiz-Abajo, M. J., Gonzalez-Ferrero, C., Moreno-Ruiz, A., RomoHualde, A., \& Gonzalez-Navarro, C. J. (2013). Thermal protection of beta-carotene in re-assembled casein micelles during different processing technologies applied in food industry. Food Chemistry, $138,1581-1587$.

Sangeetha, J., \& Philip, J. (2012). The interaction, stability and response to an external stimulus of iron oxide nanoparticle-casein nanocomplexes. Colloids and Surfaces A - Physicochemical and Engineering Aspects, 406, 52-60.

Schmitt, C. J. E., \& Bovetto, L. (2007). Whey protein vehicle for active agent delivery. European Patent Office, EP 1839498 A1.

Sekhon, B. S. (2010). Food nanotechnology - an overview. Nanotechnology, Science and Applications, 2010(3), 1-15.

Semo, E., Kesselman, E., Danino, D., \& Livney, Y. D. (2007). Casein micelle as a natural nano-capsular vehicle for nutraceuticals. Food Hydrocolloids, 21, 936-942.

Serrano-Cruz, M. R., Villanueva-Carvajal, A., Rosales, E. J. M., Davila, J. F. R., \& Dominguez-Lopez, A. (2013). Controlled release and antioxidant activity of Roselle (Hibiscus sabdariffa L.) extract encapsulated in mixtures of carboxymethyl cellulose, whey protein, and pectin. LWT - Food Science and Technology, 50, 554-561.

Shahidi, F., \& Han, X. Q. (1993). Encapsulation of food ingredients. Critical Reviews in Food Science and Nutrition, 33, 501-547.

Shapira, A., Assaraf, Y. G., Epstein, D., \& Livney, Y. D. (2010). Betacasein nanoparticles as an oral delivery system for chemotherapeutic drugs: impact of drug structure and properties on co-assembly. Pharmaceutical Research, 27, $2175-2186$.

Shapira, A., Davidson, I., Avni, N., Assaraf, Y. G., \& Livney, Y. D. (2012). Beta-casein nanoparticle-based oral drug delivery system for potential treatment of gastric carcinoma: stability, targetactivated release and cytotoxicity. European Journal of Pharmaceutics and Biopharmaceutics, 80, 298-305.

Shpigelman, A., Cohen, Y., \& Livney, Y. D. (2012). Thermally-induced $\beta$-lactoglobulin-EGCG nanovehicles: loading, stability, sensory and digestive-release study. Food Hydrocolloids, 29, 57-67.

Shpigelman, A., Israeli, G., \& Livney, Y. D. (2010). Thermally-induced protein-polyphenol co-assemblies: beta lactoglobulin-based nanocomplexes as protective nanovehicles for EGCG. Food Hydrocolloids, 24, 735-743.

Sneharani, A. H., Karakkat, J. V., Singh, S. A., \& Rao, A. G. (2010). Interaction of curcumin with beta-lactoglobulin-stability, spectroscopic analysis, and molecular modeling of the complex. Journal of Agricultural and Food Chemistry, 58, $11130-11139$

Somchue, W., Sermsri, W., Shiowatana, J., \& Siripinyanond, A. (2009). Encapsulation of $\alpha$-tocopherol in protein-based delivery particles. Food Research International, 42, 909-914.

Sugiarto, M., Ye, A., \& Singh, H. (2009). Characterisation of binding of iron to sodium caseinate and whey protein isolate. Food Chemistry, 114, 1007-1013.

Tavel, L., Moreau, C., Bouhallab, S., Li-Chan, E. C. Y., \& Guichard, E. (2010). Interactions between aroma compounds and $\beta$ lactoglobulin in the heat-induced molten globule state. Food Chemistry, 119, 1550-1556.

Thompson, A., Boland, M. J., \& Singh, H. (2009). Milk proteins, from expression to food (1st ed.). San Diego: Elsevier.

Tippetts, M., Martini, S., Brothersen, C., \& McMahon, D. J. (2012). Fortification of cheese with vitamin D3 using dairy protein emulsions as delivery systems. Journal of Dairy Science, 95, $4768-4774$.

Torres-Giner, S., \& Lagaron, J. M. (2010). Zein-based ultrathin fibers containing ceramic nanofillers obtained by electrospinning. I. Morphology and thermal properties. Journal of Applied Polymer Science, 118, 778-789.

Velikov, K. P., \& Pelan, E. (2008). Colloidal delivery systems for micronutrients and nutraceuticals. Soft Matter, 4, 1964-1980.

Viney, C. (2004). Self-assembly as a route to fibrous materials: concepts, opportunities and challenges. Current Opinion in Solid State \& Materials Science, 8, 95-101.

de Vos, P., Faas, M. M., Spasojevic, M., \& Sikkema, J. (2010). Encapsulation for preservation of functionality and targeted 
delivery of bioactive food components. International Dairy Journal, 20, 292-302.

Walstra, P., Wouters, J. T. M., \& Geurts, T. J. (2006). Dairy science and technology (2nd ed.). Boca Raton: CRC Press.

Zimet, P., \& Livney, Y. D. (2009). Beta-lactoglobulin and its nanocomplexes with pectin as vehicles for $\omega-3$ polyunsaturated fatty acids. Food Hydrocolloids, 23, 1120-1126.
Zimet, P., Rosenberg, D., \& Livney, Y. D. (2011). Re-assembled casein micelles and casein nanoparticles as nano-vehicles for $\omega-3$ polyunsaturated fatty acids. Food Hydrocolloids, 25, 1270-1276.

Zorilla, R., Liang, L., Remondetto, G., \& Subirade, M. (2011). Interaction of epigallocatechin-3-gallate with $\beta$-lactoglobulin: molecular characterization and biological implication. Dairy Science \& Technology, 91, 629-644.

\section{ScienceDirect}

\section{Essential to Research Success}

Discover ScienceDirect today and access scientific, technical and medical content from:

- More than 12 million articles and book chapters

- Close to 3,000 journal titles and 20,000 eBooks

- A growing number of freely available open access journals

- Digital archives that reach as far back as 1823

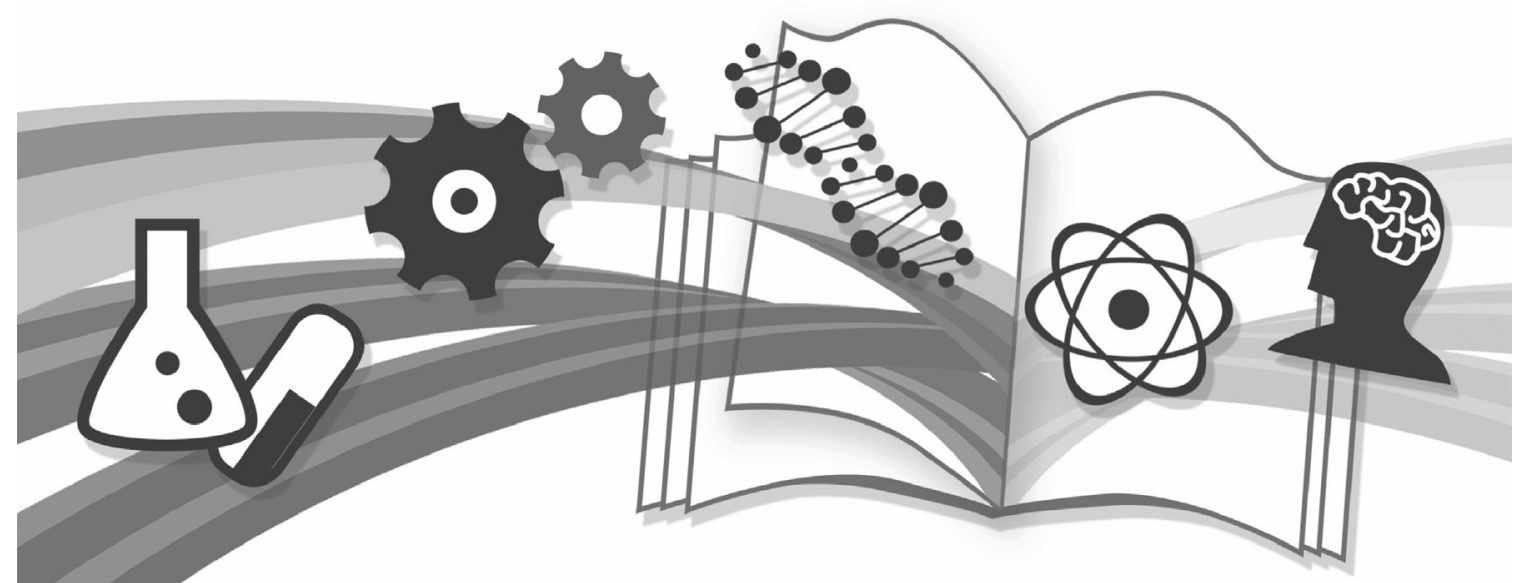

Search with confidence across:

- Physical Sciences \& Engineering

Life Sciences

- Health Sciences

Social Sciences \& Humanities

ELSEVIER Register now to take advantage of customized features and services. 